\title{
Helicobacter Pylori Infection in Peptic Ulcer Disease
}

\author{
Tat-Kin Tsang ${ }^{1}$ and Manish Prasad Shrestha ${ }^{2}$ \\ ${ }^{1}$ University of Chicago, \\ ${ }^{2}$ Saint Francis Hospital, University of Illinois \\ U.S.A
}

\section{Introduction}

\subsection{Background}

Helicobacter pylori infection is one of the most common bacterial infections worldwide.1,2 Nearly $50 \%$ of the world's population is affected. ${ }^{3}$ Though the prevalence of this infection appears to be decreasing in many parts of the world, H. pylori remains an important factor linked to the development of peptic ulcer disease, gastric malignancy and dyspeptic symptoms. ${ }^{4}$ Majority of H. pylori infected persons remain asymptomatic. Approximately $10-$ $15 \%$ of the infected persons develop associated illnesses, 1 to $10 \%$ developing peptic ulcer disease, 0.1 to $3 \%$ developing gastric cancer and less than $0.01 \%$ developing gastric mucosaassociated lymphoid tissue (MALT) lymphoma.

There are several lines of evidence implicating H. Pylori in the development of gastric and duodenal ulcers.

1. H. Pylori is found in most patients who have peptic ulcers in absence of NSAID use.

2. Presence of H. Pylori is a risk factor for the development of ulcer.

3. Eradication of H. Pylori significantly reduces the recurrence of gastric and duodenal ulcers.

4. Treatment of H. Pylori infection leads to more rapid and reliable ulcer healing than does treatment with anti-secretory therapy alone. ${ }^{15,21}$

Early studies have estimated the rate of $\mathrm{H}$. Pylori infection in patients with duodenal ulcer to be as high as $90 \%$ and in gastric ulcer to be as high as 70 to $90 \%, 5,6,7,29$ Despite the decreasing prevalence of $\mathrm{H}$. Pylori infection in developed countries, it is still an important factor in the aetiology of non-iatrogenic peptic ulcer disease. Up to $80 \%$ of duodenal ulcers and $70 \%$ of gastric ulcers are associated with $\mathrm{H}$. Pylori infection. Several studies have shown that a pre- existing $\mathrm{H}$. Pylori infection increases the risk for developing peptic ulcer disease. $8,9,10,11$ In one study, $11 \%$ of patients with $\mathrm{H}$. Pylori gastritis developed peptic ulcer disease compared to $1 \%$ of persons without gastritis. ${ }^{10}$ Eradication of $\mathrm{H}$. Pylori infection significantly reduces the recurrence of gastric and duodenal ulcers.12,13,14,21 One study reviewed the relationship between $\mathrm{H}$. Pylori eradication and reduced recurrence of duodenal and gastric ulcers. Ulcer recurrence was significantly less common among $\mathrm{H}$. Pylori cured patients versus non-cured patients $(6 \%$ versus $67 \%$ for patients with duodenal ulcers; $4 \%$ versus $59 \%$ for patients with gastric ulcers). ${ }^{12}$ 
H. Pylori has also been linked to the development of idiopathic thrombocytopenic purpura, ischemic heart disease and cerebrovascular accident. However, if confounding factors are taken into consideration, the strength of these associations is reduced.16, 17, 221

\section{Bacteriology}

Helicobacter pylori is a unipolar, multiflagellate, spiral shaped, microaerophilic, gram negative bacterium..$^{18}$ The bacterium was first isolated by Marshall and Warren in 1983 from gastroscopy biopsy specimens, which they described as a new species related to the genus Campylobacter. ${ }^{18}$ The new genus Helicobacter was first published in October 1989. At least 22 species are now included in this genus, the majority of which colonise mammalian stomachs or intestines.

Helicobacter pylori is a slow growing bacterium. It can be cultured on non-selective agar media, such as blood agar, chocolate agar or on selective agar media, such as Skirrows media incubated in a humidified, micro-aerobic ( $5 \%$ oxygen) atmosphere at 35 to 37 degree centigrade for three to seven days. ${ }^{19}$ Small, translucent circular colonies form and organisms are identified as Helicobacter pylori based on typical cellular morphology and positive results for oxidase, catalase and urease tests.

Under stress and nutritional deprivation, H. Pylori undergoes a morphological transformation from spiral bacilli to inactive coccoids. ${ }^{19} \mathrm{H}$. Pylori cell wall enzyme Ami A, a peptidoglycan hydrolase, is involved in this morphologic transition. ${ }^{20}$ Coccoid forms may be indicative of a dormant state. Coccoid forms may enable the organism to survive outside the human host in faeces or in water.

\section{Epidemiology}

Helicobacter pylori is one of the most common bacterial infections worldwide. At least $50 \%$ of the world's population is infected. The prevalence of H. Pylori infection in a community is related to three factors: 1 . Rate of acquisition of infection, i.e. the incidence 2 . the rate of loss of the infection 3. the prolonged prevalence of the bacterium in the gastro-duodenal mucosa between infection and eradication. [Prevalence is directly related to incidence and duration of illness].2 Acute H. Pylori infection invariably passes undetected. Thus, the incidence of infection is determined indirectly from epidemiological studies. The incidence of $\mathrm{H}$. Pylori infection is estimated to be approximately $0.5 \%$ per year in adults of developed countries. This incidence has been decreasing over time. However, the incidence of H. Pylori infection continues to be high in developing countries ( $3 \%$ to $10 \%$ per year). ${ }^{25}$

The infection is usually acquired in the first few years of life. Once acquired, infection persists indefinitely unless treated. In developing countries, the majority of children become infected during childhood and chronic infection continues during adulthood.2,26 By age 1 year, approximately $20 \%$ are infected and by age 10 years, $50 \%$ are infected. ${ }^{26}$ The prevalence of $\mathrm{H}$. Pylori infection may be as high as $80 \%$ in adults. 30,31 However, in developed countries, such as, the United States, evidence of infection is rare before age 10, but increases to $10 \%$ between 18 and 30 years of age and to $50 \%$ in those older than age 60.2 The higher prevalence in older age groups is thought to reflect a cohort effect related to poorer living conditions of children in previous decades. Within any age group, H. Pylori infection is more common in non-Hispanic blacks and Hispanics compared to the white population, which may be related to socioeconomic factors. 27,28 
Important risk factors for $\mathrm{H}$. Pylori infection are socioeconomic status and living conditions during childhood. Lower socioeconomic status and poor living conditions during childhood have been associated with higher risk of acquiring H. Pylori infection.38,39,40,41 There may also be genetic susceptibility to $\mathrm{H}$. Pylori infection. ${ }^{22,43}$ Twin studies support hereditary susceptibility to infection, but this has not been proven. Individuals of certain ethnic groups including Hispanics and blacks have a higher rate of infection than Caucasians, which are not entirely explained by differences in socioeconomic status. 44

\section{Helicobacter pylori transmission}

The mode of transmission of $\mathrm{H}$. Pylori infection is poorly known.1,45 Various modes of transmission have been suggested, such as person-to-person, water-borne, food-borne and zoonotic transmission. $45,46,47,48,49,50,51,52,53,54$ The transmission of $\mathrm{H}$. Pylori seems to be direct from person-to-person via faecal-oral or oral-oral routes. 45,46 Certain epidemiological studies have suggested water-borne and food-borne transmissions. ${ }^{11,52,53,54}$ Zoonotic transmission has also been suggested based on isolation of $\mathrm{H}$. Pylori from primates, domestic cats and sheep. ${ }^{47,48,49}$

Person-to person transmission is supported by the increased prevalence of infection among family members of patients with $\mathrm{H}$. Pylori and among institutionalized patients. Isolation of genetically identical strains of $\mathrm{H}$. Pylori from infected members of the same family and in patients in a chronic care facility further support this hypothesis. $32,33,34,35,36,37$ Faecal-oral transmission is a possibility as $\mathrm{H}$. Pylori has been cultured from faeces ${ }^{54,55}$ and the organism seems to survive in water in non-culturable forms ${ }^{50,51,52}$ (detected by PCR techniques). There is some indirect, but scarce evidence for oral-oral transmission. ${ }^{45} \mathrm{H}$. Pylori has been identified in dental plaques ${ }^{56}$, but it is unknown if this location can serve as a reservoir. Gastro-oral route of transmission through vomitus has also been suggested based on presence of bacteria in gastric secretions. ${ }^{57,58}$

Studies employing microbiological techniques have demonstrated that Helicobacter pylori is present in water and other environmental samples all over the world. Epidemiological studies have shown that water source and exposures related to water supply, including factors related to sewage disposal and exposure to animals, are risk factors for infection. ${ }^{51}$ Children who swim in rivers, streams, pools, drink stream water or consume raw vegetables are more likely to be infected. ${ }^{53} \mathrm{H}$. Pylori has also been detected in various food samples. So it has been hypothesised that food or water may be a reservoir in $\mathrm{H}$. Pylori transmission.

Iatrogenic transmission has also been documented after the use of inadequately disinfected endoscopes and endoscopic accessories. ${ }^{58}$

\section{Patho-physiology}

\subsection{Patho-physiology of gastric ulcers}

$\mathrm{Up}$ to $70 \%$ of gastric ulcers are associated with $\mathrm{H}$. Pylori infection. Three types of gastric ulcers have been described. Type I ulcers occur in the body of the stomach and are not related to other gastro-duodenal disease. Type II ulcers also occur in the body of the stomach and are associated with a duodenal ulcer scar or active ulcer. Type III ulcers occur in the immediate pre-pyloric area. Type II and III ulcers are associated with higher levels of gastric acid secretion as seen in patients with duodenal ulcers, but type I ulcers tend to be associated with normal or low levels of gastric acid secretion. Role of H. Pylori in these 
different types of gastric ulcer is not known. Gastric acid secretion may not be the most important factor in the development of gastric ulcers as gastric ulcers have been seen in the presence of achlorhydria. ${ }^{59}$ It has also been observed that basal and stimulated gastric acid secretion is within normal limits in groups of patients with gastric ulcers

\subsection{Patho-physiology of duodenal ulcers}

The mechanism by which Helicobacter pylori predisposes to duodenal ulcer is unclear. The pathogenesis of duodenal ulcer appears to be multi-factorial, involving an imbalance between "damaging" (e.g. acid, pepsin) and "protecting" (e.g. mucus, mucosal barrier, bicarbonate production, blood flow, cellular regeneration) factors. ${ }^{60}$ The bacterium seems to affect different aspects of gastric and intestinal mucosal physiology that may contribute to development of ulcer disease. Disturbances in gastric acid secretion, gastric metaplasia, host inflammatory and immune response and down-regulation of various mucosal defence factors may contribute to ulcer formation. Various bacterial, host and environmental factors may also have a role in the pathogenesis of duodenal ulcer.

\subsubsection{Disturbances in gastric acid secretion}

Gastric acid secretion is elevated in patients with duodenal ulcers. ${ }^{61,70}$ Helicobacter pylori infection can alter acid secretion in both directions. Acid secretion decreases temporarily during acute infection and may dwindle later if $\mathrm{H}$. Pylori causes gastric atrophy. ${ }^{63}$ In patients with duodenal ulcers, H. Pylori produces inflammation of non-acid secreting antral region of the stomach, whereas the more proximal acid-secreting fundic mucosa is relatively spared. ${ }^{70,71}$ This may explain the increased gastric acid secretion in patients with duodenal ulcers. When compared to $\mathrm{H}$. Pylori negative subjects, patients with duodenal ulcers have elevated basal acid output, peak acid output, fasting and meal-stimulated gastrin concentrations. $61,62,70$

H. Pylori infection is thought to change the physiological control of acid secretion. H. Pylori infection has been found to decrease the local expression of the inhibitory peptide somatostatin 63 and to increase the release of the acid-stimulating hormone, gastrin.62,70 Hypergastrinemia, in addition to decreased inhibitory somatostatin, may be responsible for the increased gastric acid secretion. Hypergastrinemia may result from a decrease in the inhibitory peptide somatostatin. ${ }^{64}$ Bacterial factors that inhibit somatostatin release have not been recognised, although TNF-alpha induced by H. Pylori infection may play a role in inhibiting somatostatin release. ${ }^{65}$ In patients with H. Pylori infected duodenal ulcers, there is an exaggerate response to stimulation by gastrin.61,70,71 This may be due to increased parietal cell mass in patients with duodenal ulcers ${ }^{60,66,71}$ (Duodenal ulcer patients have approximately twice the normal parietal cell mass). But it is unclear whether or not this is due to $\mathrm{H}$. Pylori infection. ${ }^{67}$ Increased parietal cell mass may be due to trophic effects of hypergastrinemia over time or it may be related to host factors.

\subsubsection{Gastric metaplasia}

Elevated gastric acid secretion increases the duodenal acid load, which damages the duodenal mucosa, causing ulceration and gastric metaplasia. Gastric metaplasia occurs in the duodenum in response to acidic $\mathrm{PH}$ (when $\mathrm{PH}$ is less than 2.5). ${ }^{68}$ Metaplastic gastric epithelium allows H. Pylori to colonise the duodenal mucosa, where it produces an acute inflammatory response. Colonization of these areas of gastric metaplasia by H. Pylori may significantly increase the risk of ulceration. ${ }^{69}$ 
However, gastric metaplasia is found in most, but not all patients with duodenal ulcers. $72,73,74$ Gastric metaplasia can also be commonly found in the duodenum of healthy persons. $73,74,75$ Studies have found a similar prevalence of gastric metaplasia among patients with duodenal ulcers and non ulcer dyspepsia. ${ }^{76}$ Therefore, the role of gastric metaplasia in the pathogenesis of duodenal ulcer disease is unclear.

\subsubsection{Host immune and inflammatory response}

Host immune system responds to $\mathrm{H}$. Pylori infection by production of inflammatory cytokines, such as interleukin(IL)-1, IL-6, tumor necrosis factor alpha, IL-8. These inflammatory cytokines may have a role in the development of duodenal ulcer.

\subsubsection{Down-regulation of mucosal defence factors}

i. Mucus- Mucus is a protective coat overlying the intestinal mucosa. Helicobacter pylori produces proteolytic enzymes that degrade this mucus layer, thus exposing the underlying mucosa to damaging effects of acid. ${ }^{77}$

ii. Bicarbonate- Most patients with duodenal ulcers have impaired proximal duodenal mucosal bicarbonate secretion. Impaired bicarbonate secretion in patients with duodenal ulcers could be caused by a cellular and/or physiological regulatory transport defect possibly related to $\mathrm{H}$. Pylori infection as eradication of the infection normalises proximal mucosal bicarbonate secretion. ${ }^{78}$

iii. Cellular regeneration- Epidermal growth factor (EGF) and transforming growth factoralpha(TGF-alpha) are potent gastric acid inhibitors and stimuli of mucosal growth and protection. H. Pylori may contribute to ulcerogenesis by affecting these factors for cellular regeneration as eradication of $\mathrm{H}$. Pylori infection has shown to increase mucosal content and expression of TGF-alpha, EGF and EGF receptor (EGFr). ${ }^{79}$

iv. Blood flow- Thrombotic occlusion of surface capillaries is promoted by a bacterial platelet activating factor. Circulating platelet aggregates and activated platelets were detected in patients with $\mathrm{H}$. Pylori infection. Platelet activation and aggregation may contribute to microvascular dysfunction. ${ }^{84}$ This may play a role in producing mucosal damage and ulcer.

\subsubsection{Other contributing factors}

i. Bacterial factors- Various bacterial factors, such as the bacterial strain may play role in the pathogenesis of duodenal ulcer. For example, Strains with the cytotoxin-associated gene $\mathrm{A}(\mathrm{cag} \mathrm{A})$ are associated with duodenal ulcer. Approximately $95 \%$ of patients with duodenal ulcers have cag $\mathrm{A}+$ strains compared to $65 \%$ of infected patients without ulcers. ${ }^{80}$

ii. A specific Helicobacter pylori gene, duodenal ulcer promoting gene (dupA) is associated with an increased risk of duodenal ulcer. One study found that dup A was present in $42 \%$ of patients with duodenal ulcer versus $21 \%$ of patients with gastritis (adjusted odds ratio[OR]=3.1, 95\% confidence interval; CI-1.7-5.7). ${ }^{81}$ Its presence was also associated with more intense antral neutrophil infiltration and interleukin-8 levels and was a marker for protection against gastric atrophy, intestinal metaplasia, and gastric cancer. 81,82

iii. Host factors- Host factors may be important in the development of duodenal ulcer. For example, patients with Helicobacter pylori who develop duodenal ulcer have higher 
parietal cell mass or sensitivity to gastrin than Helicobacter pylori infected healthy persons. ${ }^{60,66,71}$

iv. Environmental factors, such as NSAID use and smoking may also increase the risk of duodenal ulcer in patients with Helicobacter pylori infection. ${ }^{83}$

\subsection{Pathogenesis of $\mathrm{H}$. Pylori-induced peptic ulcer disease}

H. pylori causes three major gastric morphologic changes. 87 The extent and distribution of H. Pylori-induced gastritis ultimately determine the clinical outcome. The commonest morphologic change is the "simple or benign gastritis", characterized by mild pangastritis with little disruption of gastric acid secretion. This form of gastritis is commonly seen in asymptomatic people with no serious gastrointestinal disease. Up to $15 \%$ of infected subjects develop an antral-predominant gastritis with relative sparing of the acid producing corpus mucosa. Subjects with antral-predominant gastritis have high antral inflammatory scores, high gastrin levels, relatively healthy corpus mucosa and very high acid output.70 These abnormalities lead to the development of peptic ulcers, particularly duodenal and a large proportion of pre-pyloric ulcers. Up to $1 \%$ of infected subjects develop a corpus predominant pattern of gastritis, gastric atrophy and hypo- or achlorhydria. ${ }^{85}$ These abnormalities develop as a direct result of the chronic inflammation induced by the infection and increase the risk of gastric cancer.

It is believed that the complex interplay between the host and the bacterium determines the disease outcome. Various bacterial factors have been described which aid in the colonisation of the gastric mucosa and subsequent modulation of the host's immune response. Studies have investigated the impact of these bacterial factors on inflammation and disease outcome. Role of bacterial factors for disease outcome remains limited, with most "virulent" strains being found in asymptomatic subjects. ${ }^{86}$ Therefore, the variation in the host's inflammatory and immune response to infection may play a key role in determining the disease outcome. Nonetheless, the bacterium is required to initiate the host's response.

\subsubsection{Bacterial factors}

\section{i. Colonisation/ Bacterial attachment}

$\mathrm{H}$. pylori is very sensitive to acid and it dies rapidly in the acidic $\mathrm{PH}$ found in the gastric lumen. Bacterial motility, urease and its ability to adhere to gastric epithelium are the factors that allow it to survive in the acidic environment. ${ }^{87}$

Various changes are observed in H. Pylori expression of genes following exposure to low $\mathrm{PH}$. There is an increase in the expression of genes encoding proteins involved in the motility apparatus as well as genes encoding urease and proteins associated with the optimal function of the urease. ${ }^{88}$ These observations suggest that the bacterial genes are turned on in the gastric mucosa.

H. pylori is capable of swimming freely within the mucus gel by utilising its polar flagella. It seems that the bacterium is able to sense and respond to $\mathrm{PH}$ gradients by swimming away from the acidic $\mathrm{PH} .{ }^{89}$ This allows the bacterium to swim away from the acidic $\mathrm{PH}$ in the gastric lumen to the close proximity of gastric epithelium, where the $\mathrm{PH}$ is near normal. In this environment, it enjoys the same cytoprotective mechanism as the gastric epithelium.

Other remarkable feature of $\mathrm{H}$. Pylori is its ability to produce large amounts of cytosolic and cell surface associated urease. The urease produced by $\mathrm{H}$. Pylori functions optimally at 2 different PH values, 7.2 and $3 .{ }^{91}$ Cell-surface associated urease hydrolyses gastric luminal 
urea to ammonia that helps neutralise gastric acid and form a protective cloud around the bacterium. ${ }^{92}$ Within H. Pylori's urease gene cluster, there is a specific gene, Ure I, which encodes for a PH dependent urea channel. ${ }^{22}$ The urea channel allows movement of urea from gastric lumen into the cytoplasm. The metabolism of urea by the cytosolic urease generates ammonia ions, which buffer hydrogen ions as they reach the cytoplasm of the organism. ${ }^{93,94}$

H. pylori infects gastric type epithelium to which it adheres closely. Adherence of the bacterium to the gastric epithelium is an important virulence factor and is necessary for the induction of pro-inflammatory responses. Adhesion to gastric epithelium may be beneficial to the bacterium in many ways. It may protect the bacterium against the mechanical clearance. Adhesion may promote invasion and persistence. The bacterium may use the cell surface as a site of replication. Increased inflammation and cellular damage caused by adhesion may release nutrients for $\mathrm{H}$. Pylori. Adhesion also plays a major role in the delivery of toxins such as, Cag A and Vac A to host epithelial cell. ${ }^{87}$

Approximately $20 \%$ of $\mathrm{H}$. Pylori in the stomach are found attached to the surfaces of mucus epithelial cells. ${ }^{90}$ Adhesion is mediated by specific interactions between bacterial adhesin(s) and host receptor(s). ${ }^{23,24}$ Over 30 genes in H. Pylori genomes are dedicated to the expression of outer membrane proteins (OMPs). Several of these OMPs have been classified as adhesins. Best described adhesins are BabA, Oip A and SabA. The leb-binding adhesin, BabA mediates binding to fucosylated Lewis $b($ Leb $b)$ histo-blood group antigen on gastric epithelial cell.95 Epidemiological studies also provide evidence in support of interaction between Leb and Bab A. For example, Strains of H. Pylori with BabA2 genotype are associated with inflammation, duodenal ulcer and gastric cancer.96,97 Outer membrane protein (Oip A) coded by HPO638 gene may act as adhesins as well as promote inflammation by inducing IL-8 production..$^{98}$ However, their receptors have not yet been characterized. Sialic acid-binding adhesin (SabA) mediates binding to sialyl-dimeric-Lewix $X$ glycosphingolipid in gastric epithelial cell. ${ }^{99}$ Many strains of $\mathrm{H}$. Pylori express a vacuolating cytotoxin Vac A, which may serve as a ligand for bacterial attachment. Although the majority of the Vac A is secreted, some may remain on the surface of the bacteria and serve as a ligand for bacterial attachment to epithelial cells, via an interaction with protein tyrosine phosphatases. 100 The Alp A and Alp B proteins have also been described as as adhesins in vitro. ${ }^{101}$ However, there is a marked heterogeneity in H. Pylori adhesion system. ${ }^{102}$ No individual adhesin is necessary for attachment to the gastric mucosa. Expression of adhesins is diverse between strains and variable within a single strain over time and these mechanisms of variability and adaptation are controlled at the genetic level by on/off switching of adhesin gene expression, gene inactivation or recombination. $87,102,103,104,105$

Le antigens expressed by host cells may serve as the major receptor for bacterial binding. ${ }^{106,107}$ Bab A mediates binding to Leb receptor on host cell. However, there may be other host molecules besides Le antigens that can bind H. Pylori as it has been seen that the binding of $\mathrm{H}$. Pylori to epithelial cells freshly isolated from human gastric biopsy specimens is unaffected by the expression of Le antigen 108 and individuals who do not express Leb can clearly be infected with $\mathrm{H}$. Pylori. ${ }^{109}$ One such host molecule may be class II major histocompatibility (MHC) molecule expressed on the surface of gastric epithelial cell. ${ }^{110} \mathrm{H}$. Pylori can bind to class II MHC molecules on the surface of gastric epithelial cells and induce apoptosis. ${ }^{111}$ A family of pathogen-associated molecular pattern receptors, the Tolllike receptors(TLRs) have also been examined for their role in binding of $\mathrm{H}$. Pylori to the 
host epithelial cells. 11 TLRs have been described. ${ }^{86}$ Each one appears to have a different specificity for various bacterial molecules. ${ }^{112}$ These receptors may bind bacterial products and thereby, enhance both bacterial binding and signalling. For example, TLR5 binds bacterial flagellins ${ }^{113}$, TLR4 binds bacterial lipopolysaccharide(LPS). ${ }^{114,115}$ The gastric trefoil protein TFF1, predominantly expressed in the gastric mucosa and the gastric mucus may serve as another receptor for H. Pylori. ${ }^{116} \mathrm{~A}$ host cell glycosylphosphatidylinositol( GPI)anchored glycoprotein, DAF has also been described as a potential receptor for binding $\mathrm{H}$. Pylori. 117

\section{ii. Virulence factors}

H. pylori induced gastritis and damage to the gastric mucosa is probably secondary to immune recognition of the bacteria and damage from various bacterial products. ${ }^{87}$ Various bacterial products have been described as "toxins" based on biological activity.

\section{Vac A}

Many strains of H. Pylori express a pore forming cytotoxin, Vac A. ${ }^{118}$ Vac A has been shown to cause cell injury in vitro and gastric tissue damage in vivo. ${ }^{23,120,121}$ However for Vac $\mathrm{A}$ to cause cell damage, it must be secreted from the bacteria and delivered in an active form to host cell membranes where it assembles into pores that allow the leakage of chloride ions. ${ }^{122}$ The Vac A gene shows a considerable genetic diversity. The activities of different alleles of the toxin vary in their toxicity. For example, strains harbouring s1 types of Vac A are highly associated with ulcers and gastric cancer. ${ }^{123}$ M1 types of Vac A are also associated with ulcers. ${ }^{123}$ Although the majority of Vac A is secreted, some remain associated with the bacterial cell surface. The Vac A molecules that remain on the surface of the bacteria are functional and delivered to host cells by direct contact between adhered bacteria and the host cell membrane. ${ }^{124}$ As described earlier, Vac A on the surface of the bacteria may also serve as a ligand for bacterial attachment via an interaction with protein tyrosine phosphatases.

Several toxigenic properties of Vac A have been described that may contribute to the development of the disease. ${ }^{125,126}$ Vac A may lead to vacuolation of epithelial cells, probably through its effect on endosomal maturation. ${ }^{87}$ Vac A also induces apoptosis of host cells, probably through the activation of pro-apoptotic signalling molecules ${ }^{127}$ and pore formation in mitochondrial membranes. ${ }^{128}$ Vac A may disrupt the barrier function of tight junctions, leading to the leakage of ions and small molecules, such as iron, sugars and amino acids.129 Vac A was also found to be a powerful inhibitor of T-cell activation in vitro. ${ }^{130}$

\section{Cag $A$ and the cag Pathogenicity island (Cag PAI)}

Cag A is an important virulence factor associated with H. Pylori. It was initially thought to be the most important virulence factor as patients with antibodies against this protein showed higher rates of peptic ulcer disease ${ }^{119}$ and gastric cancer. 131,132,133 Cag A positive strains have also been associated with increased inflammation ${ }^{134}$, cell proliferation ${ }^{135}$ and gastric metaplasia. 136 However, 30 to $60 \%$ of patients infected with CagA + strains do not develop any significant disease. 80 Therefore, Cag A may not be the most important virulence factor.

Cag A is a 128 to $140 \mathrm{kd}$ protein, that can activate a number of signalling mechanisms and thus, affect the structure, differentiation and behaviour of epithelial cells. ${ }^{87} \mathrm{Cag} \mathrm{A}$ is translocated into the host cell by the type 4 secretion system( TFSS). Genes within the cag pathogenicity island(PAI) encode proteins for the type 4 secretion apparatus(TFSS), also 
referred to as Cag E.125,137 These genes are co-transcribed and are genetically linked to Cag A.120 TFSS allows bacterial macromolecules, such as Cag A, peptidoglycan to be translocated into the host cell.125,137 The intact cag PAI of H. Pylori plays an important role in the pathogenesis of gastritis.125,137,138 For example, Mutations of H. Pylori cag region were associated with decreased gastric mucosal inflammation in vivo and reduced activation of IL-8 or apoptosis in vitro. ${ }^{139}$ It is believed that cag PAI results in the activation of nuclear factor(NF-kb) and AP-1, which in turn, regulate the expression of a wide variety of proinflammatory cytokines. ${ }^{140,141}$ Cag PAI may collaborate with other bacterial factors, such as Oip A to enhance IL-8 production. ${ }^{142}$ Bacterial peptidoglycan may also leak into the cell through the TFSS, resulting in the activation of Nod-1 mediated inflammatory response. ${ }^{143}$ Once inside the host cell, Cag A is tyrosine phosphorylated by host Src kinases. ${ }^{144}$ Src kinases are normally involved in controlling basic cytoskeletal process, cell proliferation and differentiation. After its tyrosine phosphorylation, it interacts with a number of host proteins, triggering growth receptor-like signalling. Through these signal transduction events, Cag A affects the proliferative activities, adhesion and cytoskeletal organisation of epithelial cells. ${ }^{87,145,146,147}$ Cag A also perturbs cell cycle control.148 Cag A may also have a phosphorylation independent effect on gene transcription. ${ }^{149}$ Independently of tyrosine phosphorylation, Cag A can form complexes with several junction proteins such as Zo-1, JAM and E-cadherin and can perturb the assembly and function of both the tight junction and the adherens junctions. ${ }^{150,151}$ Phenotypically, this leads to the deregulation of epithelial cell-cell adhesion and loss of epithelial polarity. ${ }^{152}$ Cag A, independent of cag TFSS, can activate the nuclear factor, NF-kb leading to activation of pro-inflammatory signal and IL-8 secretion. ${ }^{140,141}$ Cag A may also induce DNA damage and apoptosis of gastric epithelial cells via oxidative stress. ${ }^{171}$

\section{Other virulence factors}

Most persons infected with H. Pylori strains that produce Vac A and possess Cag A genotype nonetheless remain asymptomatic, suggesting that additional virulence factors are important in virulence. Several other $\mathrm{H}$. Pylori virulence factors, such as ice A, Bab A2, Oip A have been described.153,154,155,156,157 For example, "induced by contact with epithelium" ice A has been linked to peptic ulcers and increased mucosal concentrations of IL-8. ${ }^{153,154,155} \mathrm{H}$. Pylori strains with "blood group antigen binding adhesin" Bab A2 genotype are associated with inflammation, duodenal ulcer and gastric cancer ${ }^{156}$. Oip A has been associated with duodenal ulcers. ${ }^{157}$ However, the importance of these virulence factors in the life of $\mathrm{H}$. Pylori is poorly understood.

iii. Mechanism of persistence

In order to colonise the human stomach, H. Pylori must overcome the physical and chemical barriers as well as innate and adaptive immune responses that are triggered in the stomach by its presence. ${ }^{87} \mathrm{H}$. Pylori urease functions mainly as a protective buffering enzyme against gastric acidity. Several bacterial factors including catalase and urease antagonise innate host immune responses. ${ }^{158} \mathrm{H}$. Pylori may decrease the expression of the antibacterial molecule secretory leukocyte protease inhibitor. ${ }^{159} \mathrm{H}$. Pylori produces an enzyme, arginase that inhibits nitric oxide production and may favour bacterial survival. ${ }^{160}$ Virulent strains of $\mathrm{H}$. Pylori may alter mucus production ${ }^{161}$ and phagocytosis. ${ }^{162}$ A number of H. Pylori factors may actually contribute to reduce inflammation or recognition by the immune system. Molecular mimicry may be an important mechanism employed by the bacterium to evade recognition by the host immune system. For example, H. Pylori flagellar proteins have 
evolved to avoid being recognised by toll-like receptors. ${ }^{163} \mathrm{H}$. Pylori lipopolysaccharides mimic host molecules such as Lewis antigens. ${ }^{164} \mathrm{H}$. Pylori virulence factors elicit both proinflammatory cytokines such as INF-gamma, TNF-alpha and anti-inflammatory cytokines, such as IL-4, !L-10 and transforming growth factor-beta. These anti-inflammatory cytokines may impair immune responses and may favour persistence. ${ }^{86}$ However, these antiinflammatory cytokines, IL-4, IL-10 and TGF-b are not expressed to the same levels as proinflammatory cytokines. $165,166,167,182$ Hence, it has been hypothesized that $\mathrm{H}$. Pylori induces a robust, but specific form of chronic inflammation that is ineffective in clearing the infection while avoiding forms of inflammation that would eliminate it. ${ }^{87}$ This may be due to inappropriate T-cell responses or a lack of coordination in T-cell responses required for immunity. ${ }^{86} \mathrm{~A}$ number of host polymorphisms may also lead to variations in the immune response. 87

\subsubsection{Role of host response in $\mathrm{H}$. Pylori induced disease}

As described earlier, the host response to $\mathrm{H}$. Pylori infection is an important component in the pathogenesis of gastro-duodenal disease. H. Pylori induce chronic inflammation in the gastric mucosa, mediated by an array of pro- and anti-inflammatory cytokines. Heterogeneity in the regions of genome that control the magnitude of inflammation is thought to determine an individual's ultimate clinical outcome. For example, genetic polymorphisms in the regions controlling IL-1 beta were associated with an increased incidence of hypochlorhydria, gastric cancer and decreased occurrence of duodenal ulcer. ${ }^{168,169}$ Il-1 beta has a profound pro-inflammatory effect and it is also a powerful acid inhibitor. ${ }^{170}$ The pro-inflammatory genotypes of TNF-alpha, IL-8 and IL-10 were associated with the development of gastric cancer. ${ }^{168}$

\section{i. Epithelial cell response to H. Pylori infection}

The epithelial cell response to $H$. Pylori infection is determined by several variables: bacterial virulence factors, the signalling linked to specific receptors that recognise the bacterial components and the local effects of hormones, neurotransmitters, immune/inflammatory cytokines and stromal factors. ${ }^{86}$ These responses include changes in epithelial cell morphology ${ }^{175}$, increased epithelial cell proliferation ${ }^{176}$, increased rates of epithelial cell death via apoptosis 177 , disruption of the tight junctional complexes150, the production of inflammatory cytokines ${ }^{137}$ and induction of numerous genes, most importantly genes involved in the regulation of the immune/inflammatory responses, epithelial cell turn over including apoptosis and proliferation and those affecting physiological properties in the stomach.178,179,180,181 The expression of these genes in epithelial cells is modulated by transcription factors that are controlled by a series of signalling mechanisms. For example, nuclear factor $k b(\mathrm{NF}-\mathrm{kb})$ and $\mathrm{AP}-1$ regulate the expression of pro-inflammatory cytokines and cellular adhesion molecules in response to infection. ${ }^{182,183}$ These transcription factors are controlled by several signalling mechanisms including mitogen-activated protein kinases(MAPKs).138,184 The MAPK cascades regulate several cell functions including proliferation, inflammatory responses and cell survival. ERK and P38 MAPK pathways regulate IL-8 production in gastric epithelial cells. ${ }^{185,186}$ ERK and P38 also regulate the expression of other inflammatory response genes. Specific bacterial products as described earlier activate different transcription factors, which collaborate to enhance IL-8 production. ${ }^{86}$ Interleukin-8 and related peptides in chemokine family secreted by gastric epithelial cells recruit and activate neutrophils and macrophages. 


\section{ii. Host responses in the lamina propria}

Although H. Pylori resides predominantly in the gastric lumen, it induces a robust inflammatory and immune response. The magnitude of the host inflammatory response cannot be explained solely based upon the host epithelial cell responses to the bacterium. Significant amounts of bacterial product may leak around epithelial cells and reach the lamina propria, where it can activate phagocytes, including macrophages and neutrophils. ${ }^{86}$ Disruption of epithelial tight junctions may enhance bacterial antigen delivery to the lamina propria. Several studies have demonstrated the ability of $\mathrm{H}$. Pylori to invade gastric epithelial cells in vitro and in vivo. ${ }^{172,173}$ Transmission electron microscopy and immunogold detection have shown $\mathrm{H}$. Pylori to be in direct contact with immune cells of the lamina propria in the majority of cases of gastritis. ${ }^{174}$ Engulfment of H. Pylori infected epithelial cells by phagocytes may be one of the mechanisms by which $\mathrm{H}$. Pylori can activate the host immune response. ${ }^{187}$

Several bacterial products have been shown to trigger immune response within the lamina propria. A broad array of cytokines is released in the lamina propria in response to intact bacteria or bacterial factors. One such bacterial factor is $\mathrm{H}$. Pylori neutrophil-activating protein, a 150 kilodalton protein, which promotes neutrophil adhesion to endothelial cells and stimulates chemotaxis of monocytes and neutrophils. ${ }^{188}$ Bacterial urease can induce he production of IL-6 and TNF-alpha by macrophages. ${ }^{189}$ Heat shock protein 60 induces the production of IL-6. 190 Intact bacteria can induce the production of chemokines that recruit Tcells ${ }^{191}$ as well as IL-12192 and IL-18193, that favour the selection of Th1 cell. Increased IL-1, IL-6, IL-8 and TNF-alpha in response to H. Pylori infection recruit and activate monocytes and neutrophils. Release of neutrophil mediators may in turn, disrupt epithelial cells and contribute to ulcer formation.

\section{iii. Gastric T-cell responses}

Bacterial activation of epithelial cells, monocytes, macrophages and neutrophils leads to a Thelper cell type of adaptive response.194,195 Different T-helper cell subsets emerge in response to infection with characteristic cytokine production. In H. Pylori infection, T-cell response is predominantly of T-helper cell 1(Th1) type.138,196 Th1 cells promote cell-mediated immune responses, mainly through the production of INF-gamma and TNF-alpha while Th2 cells promote humoral immunity through the production of cytokines, such as IL-4, IL5, IL-10 and IL-13. Previously, it was thought that the gastric mucosa is pre-conditioned to favour Th1 cell development. ${ }^{165,192,197}$ One possible hypothesis is that H. Pylori selectively blocks Th2 development by interfering with STAT6 activation by IL-4. ${ }^{198}$ IL-12 and IL-18 induced in response to infection may positively select for the Th1 response. ${ }^{86}$ Activated Th1 cells produce INF-gamma and TNF-alpha which increase the expression of many proinflammatory genes in the epithelium including IL-8. ${ }^{182}$ These cytokines also enhance bacterial binding 110 and may contribute to increased bacterial load.199 Th1 cells may induce epithelial cell death through Fas-Fas L interactions.200 In summary, Th1 activation may contribute to more severe inflammation and mucosal damage. However, Th1 type of T-cell response is a type of cell-mediated immunity against the control of intracellular pathogens. ${ }^{196}$ It is unlikely to be effective against H. Pylori which is largely an extracellular pathogen. Hence, Th1 cell activation may produce inflammation, but not effective one which would clear the infection. In addition to Th1 cells, a subset of anti-inflammatory T-cells may be activated by $\mathrm{H}$. Pylori infection. These cells may impair excessive inflammation which would otherwise lead to the clearance of the organism. ${ }^{86}$ 
iv. Gastric B-cell responses

Gastric T-cells can modulate B-cell responses, leading to the production of specific antibodies to a variety of $\mathrm{H}$. Pylori antigens. During infection with H. Pylori, Ig G, Ig A and Ig M types of antibodies can be detected. ${ }^{201,202}$ The role of these antibodies in the disease is poorly understood. Ig G class of antibody can activate complement and may contribute to immune-complex mediated inflammation. ${ }^{203}$ In addition to producing antigen-specific antibodies, B-cells have also been shown to produce auto-reactive antibodies, that may be pathogenic. ${ }^{204,205}$

\section{Indications for $\mathbf{H}$. pylori testing}

H. pylori is a common worldwide infection. The vast majority of patients with H. Pylori infection do not develop clinically significant gastroduodenal disease. Therefore, routine testing for $\mathrm{H}$. Pylori is not recommended. When to test a patient for H. Pylori infection is an important question for a clinician. Guidelines from the American college of Gastroenterology [ACG] and the European Helicobacter study group [EHSG] have been published to assist clinicians in making this decision.

ACG recommendations 206

Testing for H. Pylori should only be performed if the clinician plans to offer treatment for positive results.

Testing is indicated in patients with

1. Active peptic ulcer disease( gastric or duodenal ulcer)

2. Confirmed history of peptic ulcer disease( not previously treated for H. Pylori)

3. Gastric MALT lymphoma( low grade)

4. After endoscopic resection of early gastric cancer

5. Uninvestigated dyspepsia( depending upon H. Pylori prevalence)

The test-and-treat strategy for $\mathrm{H}$. Pylori infection is a proven management strategy for patients with uninvestigated dyspepsia who are under the age of $55 \mathrm{yr}$ and have no "alarm features" ( bleeding, anaemia, early satiety, unexplained weight loss, progressive dysphagia, odynophagia, recurrent vomiting, family history of GI cancer, previous esophagogastric malignancy)

Deciding which test to use in which situation relies heavily upon whether a patient requires evaluation with upper endoscopy and an understanding of the strengths, weaknesses, and costs of the individual test.

EHSG recommendations 207

Testing is indicated in patients with

1. Gastroduodenal diseases such as peptic ulcer disease and low grade gastric MALT lymphoma

2. Atrophic gastritis

3. First degree relatives of patients with gastric cancer

4. Unexplained iron deficiency anaemia

5. Chronic Idiopathic thrombocytopenic purpura (ITP)

The test-and-treat strategy using a non-invasive test is recommended in adult patients with persistent dyspepsia under the age of 45 and no "alarm symptoms".

Testing is not recommended in GORD. However, testing should be considered in patients on long-term maintenance therapy with PPIs. 
Testing should be considered in patients who are naive NSIADs users.

Testing should be considered in patients who are long-term aspirin users who bleed.

Children with recurrent abdominal pain, who have a positive family history of peptic ulcer and gastric cancer should be tested for $\mathrm{H}$. Pylori after exclusion of other causes.

\section{Duodenal and gastric ulcer}

Testing for H. Pylori is indicated in patients with confirmed gastric or duodenal ulcers. As described earlier, H. Pylori has been established as a major risk factor for both duodenal and gastric ulcers. H. Pylori eradication has also shown to reduce the recurrence of peptic ulcer disease. Therefore, both ACG and EHSG recommend testing patients with peptic ulcer disease for H. Pylori.

\section{Gastroduodenal bleeding}

A meta-analysis performed by Sharma et al showed that $\mathrm{H}$. Pylori treatment decreased recurrent ulcer bleeding by $17 \%$ and $4 \%$ compared with ulcer healing treatment alone ( bismuth, ranitidine or omeprazole) or ulcer healing treatment followed by maintenance therapy respectively.208 Another study performed in Taiwanese patients with a history of ulcer bleeding showed that maintenance acid suppression was not routinely necessary to prevent ulcer recurrence after successful H. Pylori cure and ulcer healing. ${ }^{209}$ Therefore, patients with a bleeding duodenal or gastric ulcer should be treated for H. Pylori.

\section{Uninvestigated dyspepsia}

The Cochrane Systematic review confirmed that there is a small benefit of eradicating $\mathrm{H}$. Pylori in patients with non-ulcer dyspepsia. ${ }^{210}$ Eradication of $\mathrm{H}$. Pylori may also reduce the incidence of peptic ulcer in patients with ulcer-like functional dyspepsia.211 Therefore, the test-and-treat strategy is recommended in patients with uninvestigated dyspepsia who are under the age of 55 yrs or 45 yrs (depending upon the specific set of guidelines) and have no "alarm features". However, this strategy has been criticised. In a placebocontrolled trial of empirical treatment involving 294 patients with uninvestigated dyspepsia and a positive $\mathrm{H}$. Pylori breath test, the 1-year rate of symptom resolution was $50 \%$ in those receiving $\mathrm{H}$. Pylori eradication therapy, as compared with $36 \%$ of those receiving placebo $(p=0.02)^{212} ; 7$ patients would need to receive eradication therapy for 1 patient to have a benefit. This suggests that most patients treated with the test-and-treat strategy would incur the inconvenience, costs and potential side-effects of therapy without a benefit.

\section{Long-term maintenance therapy with PPIs}

EHSG suggests H. Pylori testing in patients on long-term maintenance therapy with PPIs. Patients who are infected with H. Pylori and maintained on a PPI may be at risk for the development of atrophic gastritis. ${ }^{213}$ However, the findings have not been confirmed in other studies. ${ }^{214}$

\section{Persons using NSAIDS or Aspirin}

EHSG suggests H. Pylori testing in patients who are naive NSAIDs users. A meta-analysis of five studies including 939 patients showed that $\mathrm{H}$. Pylori eradication was associated with a reduced incidence of peptic ulcer in patients taking NSAIDs(OR 0.43, 95\% CI 0.20-0.93). Subanalyses demonstrated that risk reduction was evident in NSAID-naive individuals, but not for those previously taking NSAIDs. 215,219 


\section{Iron-deficiency anaemia}

EHSG recommends H. Pylori testing and eradication in patients with unexplained iron deficiency anaemia. There is emerging evidence to suggest that eradication of H. Pylori can improve iron deficiency anaemia 216,217 , but the available data do not prove cause and effect.

\section{Chronic ITP}

EHSG recommends H. Pylori testing and eradication in patients with chronic ITP. The available data support an association between H. Pylori infection and ITP. ${ }^{218}$ Studies have also shown that there is a significant increase in platelet count in patients with ITP after $\mathrm{H}$. Pylori eradication. $220,222,223,224$

\section{Prevention of gastric cancer}

ACG recommends $\mathrm{H}$. Pylori testing after endoscopic resection of early gastric cancer. EHSG recommends $\mathrm{H}$. Pylori testing and eradication in first-degree relatives of patients with gastric cancer. Whether $\mathrm{H}$. Pylori eradication reduces the risk of developing gastric cancer is unknown. H. Pylori eradication may protect against the progression of premalignant gastric lesions. ${ }^{225,226} \mathrm{H}$. Pylori eradication may decrease the risk of developing cancer in individuals without precancerous lesions from high risk populations.227 However, this may not apply to low-risk populations.

\section{Diagnostic tests for H. pylori infection}

Diagnostic tests for H. Pylori can be divided into endoscopic and non-endoscopic tests. Various diagnostic tests for H. Pylori infection are shown in Table 1-2. All the methods currently available for the detection of $\mathrm{H}$. Pylori have their advantages and disadvantages regarding sensitivity, specificity, convenience, cost and immediacy. Choosing among these tests depends upon the clinical circumstance, the pre-test probability of infection, the accuracy of the tests, the availability and the relative costs.

\section{General recommendations from ACG}

When endoscopy is indicated, the test of first choice is the rapid urease test (RUT) in patients who have not been on a PPI within 1-2 week or an antibiotic or bismuth within 4 week of endoscopy.

For patients who have been taking a PPI, antibiotics or bismuth, it is appropriate to obtain biopsies from the gastric body and antrum for histology with or without RUT or plan testing with Urea breath test(UBT) or faecal antigen test(FAT) at a later date after withholding the offending agents for an appropriate period of time.

Culture or PCR is not routinely recommended.

UBTs and faecal antigen tests provide reliable means of identifying active $\mathrm{H}$. Pylori infection before antibiotic therapy.

In the setting of acute upper GI bleeding, a positive RUT indicates the presence of active $\mathrm{H}$. Pylori infection, whereas a negative RUT and/or histology should be confirmed with another test. An antibody test provides a reasonably sensitive testing option. Alternatively, patient can undergo a UBT or FAT at a later date after withholding medications that can negatively affect the sensitivity of these tests for an appropriate period of time.

Antibody testing for $\mathrm{H}$. Pylori is appropriate in patients with uninvestigated dyspepsia in regions where the prevalence of $\mathrm{H}$. Pylori infection is high. In low prevalence populations 
(prevalence less than 20\%), antibody tests should be avoided altogether or positive results should be confirmed with a test that identifies active infection, such as UBT or FAT prior to initiating eradication therapy.

\begin{tabular}{|c|c|c|}
\hline Tests & Advantages & Disadvantages \\
\hline \multicolumn{3}{|l|}{ Non- Endoscopic } \\
\hline $\begin{array}{l}\text { 1.Urea Breath Test } \\
\left(13_{C} \& 14_{C}\right)\end{array}$ & $\begin{array}{l}\text { - } \quad \text { Rapid, inexpensive and } \\
\text { identifies active } \\
\text { infection. } \\
\text { - Excellent PPV } \\
\text { regardless of H. Pylori } \\
\text { prevalence. } \\
\text { - Useful after H. Pylori } \\
\text { therapy. }\end{array}$ & $\begin{array}{l}\text { - False negative results may } \\
\text { be observed in patients who } \\
\text { are taking PPIs, bismuth or } \\
\text { antibiotics. } \\
\text { May not be available } \\
\text { consistently. }\end{array}$ \\
\hline $\begin{array}{l}\text { 2.Serological Test or } \\
\text { Antibody Test }\end{array}$ & $\begin{array}{ll}\text { - } & \text { Widely available. } \\
\text { - } & \text { Least expensive test. } \\
\text { - } & \text { Excellent NPV. }\end{array}$ & $\begin{array}{l}\text { The PPV is greatly } \\
\text { influenced by the } \\
\text { prevalence of H. pylori } \\
\text { infection. } \\
\text { Not recommended for } \\
\text { confirming eradication as } \\
\text { positive results may reflect } \\
\text { past rather than current } \\
\text { infection. }\end{array}$ \\
\hline 3. Fecal Antigen Test & $\begin{array}{l}\text { - } \quad \text { Identifies active H. } \\
\text { pylori infection. } \\
\text { High positive and } \\
\text { negative predictive } \\
\text { values. } \\
\text { - Useful before and after } \\
\text { H. Pylori treatment. }\end{array}$ & $\begin{array}{l}\text { - Collecting stool may be } \\
\text { unpleasant to patients. } \\
\text { False negative results may } \\
\text { be observed in patients who } \\
\text { are taking PPIs, bismuth or } \\
\text { antibiotics. } \\
\text { Polyclonal test less well } \\
\text { validated. }\end{array}$ \\
\hline $\begin{array}{l}\text { Endoscopic } \\
\text { 1.Rapid Urease } \\
\text { Testing }\end{array}$ & $\begin{array}{l}\text { - Rapid, inexpensive and } \\
\text { accurate in properly } \\
\text { selected patients. }\end{array}$ & $\begin{array}{l}\text { - False negative results may } \\
\text { be observed in patients who } \\
\text { are taking PPIs, bismuth or } \\
\text { antibiotics. }\end{array}$ \\
\hline
\end{tabular}




\begin{tabular}{|c|c|c|}
\hline $\begin{array}{l}\text { 2.Histological } \\
\text { assessment }\end{array}$ & $\begin{array}{l}\text { - High sensitivity and } \\
\text { specificity. }\end{array}$ & $\begin{array}{ll}- & \text { Expensive. } \\
\text { - } & \text { Requires trained personnel. }\end{array}$ \\
\hline 3. Culture & $\begin{array}{l}\text { - } \quad \text { Excellent specificity. } \\
\text { Allows determination of } \\
\text { antibiotic sensitivities. }\end{array}$ & $\begin{array}{l}\text { - Sensitivity variable. } \\
\text { - } \quad \text { Requires infrastructure and } \\
\text { trained personnel. } \\
\text { - Expensive, time consuming, } \\
\text { difficult to perform and not } \\
\text { widely available. }\end{array}$ \\
\hline $\begin{array}{l}\text { 4. Polymerase Chain } \\
\text { Reaction }\end{array}$ & $\begin{array}{l}\text { - High sensitivity and } \\
\text { specificity. } \\
\text { Provides opportunity to } \\
\text { test for antibiotic } \\
\text { sensitivity. }\end{array}$ & $\begin{array}{l}\text { False positive results may } \\
\text { be due to contamination, } \\
\text { homologous DNA } \\
\text { sequences among various } \\
\text { species, non-specific } \\
\text { amplifications. } \\
\text { - False negative results may } \\
\text { be due to reaction failure. } \\
\text { - Methodology not } \\
\text { standardized across } \\
\text { laboratories. } \\
\text { - Not widely available. }\end{array}$ \\
\hline
\end{tabular}

Table 1.

\begin{tabular}{|lll|}
\hline Test & Sensitivity & Specificity \\
\hline Non-Endoscopic Tests & & \\
1.Urea Breath Test & $90 \%-96 \%$ & $88 \%-98 \%$ \\
2.Antibody Test & $88 \%-94 \%$ & $74 \%-88 \%$ \\
3.Fecal Antigen Test & $86 \%-96 \%$ & $92 \%-97 \%$ \\
Endoscopic Tests & & \\
1.Rapid Urease Test & $88 \%-95 \%$ & $95 \%-100 \%$ \\
2.Histology & $93 \%-96 \%$ & $98 \%-99 \%$ \\
3.Culture & $80 \%-98 \%$ & $100 \%$ \\
4.Polymerase Chain Reaction & $>95 \%$ & $>95 \%$ \\
\hline
\end{tabular}

Table 2.

Confirmation of eradication is indicated in any patients with an H. Pylori-associated ulcer, persistent dyspeptic symptoms despite the test-and-treat strategy, H. Pylori-associated MALT lymphoma and in individuals who have undergone resection of early gastric cancer. If testing to prove eradication were performed in the setting of endoscopy, histology or the combination of histology and RUT would be appropriate.

UBT is the most reliable non-endoscopic test to document eradication of $\mathrm{H}$. Pylori infection. The monoclonal FAT provides another non-endoscopic means of establishing H. Pylori cure. Testing to prove H. Pylori cure appears to be most accurate if performed at least $4 \mathrm{wk}$ after the completion of antibiotic therapy. 


\subsection{Endoscopic diagnostic tests}

Currently available biopsy-based diagnostic methods for H. Pylori infection are the rapid urease test, histology, culture and polymerase chain reaction (PCR).

\subsubsection{Rapid Urease test (RUT)}

Rapid Urease tests depend on the activity of bacterial urease. Endoscopic biopsy specimens are placed into an agar gel or on a reaction strip containing urea, a buffering agent and a $\mathrm{PH}$ sensitive dye. If H. Pylori is present, its urease cleaves urea to liberate ammonia and bicarbonate, leading to an increase in the PH and change in the colour of the dye. CLO test, Hp Fast, HUT-test, Pyloritek and Pronto Dry are some of the commercially available RUT kits. The overall performance of these tests is comparable. 228,229

Although RUTs are rapid, inexpensive and easy to perform, their sensitivity is reduced under certain circumstances. The tests may produce a false negative result in patients with active or recent bleeding from the upper gastrointestinal tract when gastric contents are contaminated with blood.230,231,232 Furthermore, these tests may give a false negative result in patients who have recently been taking proton pump inhibitors (PPIs), H2-receptor antagonists (H2RAs), antibiotics, or bismuth containing compounds. ${ }^{228 I n}$ these patients, the RUT is usually combined with other endoscopic or non-endoscopic tests to determine the presence or absence of the infection. It is also recommended to obtain biopsies from two sites, the body of the gastric angularis and greater curvature of the antrum. ${ }^{233}$ This may increase the sensitivity of the test. An alternative is to withhold the offending agents, such as PPIs or antibiotics for an appropriate period of time prior to endoscopy. The duration of the deleterious effects of medications on the sensitivity of the RUT is unknown. However, based on data from UBT, it is probably reasonable to withhold a PPI for 1-2 weeks and bismuth and antibiotics for four weeks prior to the RUT.234,235

\subsubsection{Histology}

Histological testing of gastric biopsy specimens is another method of diagnosing H. Pylori infection. A significant advantage of histology over other diagnostic tests is the ability to evaluate for pathological changes associated with $\mathrm{H}$. Pylori infection, such as gastritis, atrophy, intestinal metaplasia and malignancy. ${ }^{236}$ The presence of type B chronic gastritis (non-atrophic diffuse antral gastritis or atrophic pangastritis) may be used as a surrogate marker for the infection when organisms are not detected whereas the absence of chronic gastritis may be used as a marker for the absence of infection. However, the sensitivity of histology is affected by several factors, such as the site, number and size of gastric biopsies, method of staining, level of training of the examining pathologist and use of medications, such as bismuth, antibiotics and PPIs. It is therefore recommended to obtain a minimum of three biopsies, one from the greater curvature of the corpus, one from the greater curvature of the antrum and one from the angularis to maximize the diagnostic yield of histology.237

\subsubsection{Brush cytology}

Brush cytology may be used as an alternative to histology for the diagnosis of $\mathrm{H}$. Pylori infection, especially in patients who have an increased risk of bleeding following forces biopsy. Data with endoscopic brush cytology are encouraging, with reported sensitivity and specificity of more than $95 \% .238$ 


\subsubsection{Culture}

Bacterial culture is highly specific method for detecting active H. Pylori infection. In addition to identifying infection, it permits testing for sensitivity to anti-microbial agents. 239 However, bacterial culture is relatively insensitive ${ }^{240,241}$ and seldom performed in routine clinical practise. Not all hospital laboratories have necessary expertise or resources available to offer routine culturing. Furthermore, culturing H. Pylori is difficult, time consuming and expensive.

Culture and sensitivity testing may be useful in patients with refractory disease since the incidence of resistance is very high in this subgroup.

\subsubsection{Polymerase chain reaction (PCR)}

Detection of H. Pylori by PCR is based on the amplification of a target DNA sequence in the bacterial genome. The use of PCR for the detection of $\mathrm{H}$. Pylori from environmental samples is well documented. ${ }^{269,270}$ PCR can also be used to detect $\mathrm{H}$. Pylori in biopsy specimens. ${ }^{261,262,265}$ In fact, PCR may be more sensitive than other biopsy-based diagnostic techniques in diagnosing $\mathrm{H}$. Pylori infection. 264,265 PCR testing may be more sensitive than other biopsy based tests in detecting $\mathrm{H}$. Pylori infection in patients who are taking PPIs, H2 RAs, antibiotics or bismuth containing compounds. ${ }^{263}$ The testing is also highly specific and allows testing for antibiotic sensitivities. ${ }^{266,267,268}$

Although PCR has many advantages, its clinical use is limited due to its tendency towards false positive and false negative results. False positives can result from clinical or laboratory contamination, carry over contaminations and most importantly, similarities between the primer binding regions of $\mathrm{H}$. Pylori and other organisms especially at the 3 ' ends. False negatives can result from low number of target organisms, the presence of a specific PCR inhibitor, degenerated target DNA, and polymorphisms in the primer binding regions, especially at the $3^{\prime}$ ends, that prevent the amplification of the target DNA. Furthermore, the test is not widely available and the methodology is not standardized across laboratories.

Newer PCR techniques, such as multiplex PCR assays may reduce false positive and false negative results and thereby improve the accuracy of the test. For example, TZAM HP multiplex PCR assay amplifies 10 DNA fragments from 5 DNA regions in the genome of $\mathrm{H}$. Pylori at the same time. Amplifying more than one DNA region increases the sensitivity because the probability of amplifying several selected DNA regions is much higher than the chance of amplifying only one region. It also increases the specificity because probing different loci at the same time more accurately distinguishes one pathogen from another. ${ }^{265}$

\subsection{Non-endoscopic diagnostic tests}

Currently available non-endoscopic diagnostic tests for $\mathrm{H}$. Pylori infection are urea breath test (UBT), antibody test and fecal antigen test (FAT).

\subsubsection{Urea breat test (UBT)}

The urea breath test, like the RUT, depends on the activity of bacterial urease. The test involves the ingestion of urea, labelled with either the non-radioactive isotope ${ }^{13} \mathrm{C}$ or the radioactive isotope ${ }^{14} \mathrm{C}$, which is converted to labelled carbon dioxide by the bacterial urease. The labelled carbon dioxide can then be measured in expired air. ${ }^{242,243,244}$ Although the dose of radiation exposure in ${ }^{14} \mathrm{C}$ UBT is small, the ${ }^{13} \mathrm{C}$ UBT is preferred in children and women of child bearing potential. ${ }^{242,243}$ 
The UBT has excellent sensitivity and specificity242,243 therefore, it is considered to be the most reliable test to document $\mathrm{H}$. Pylori infection. It can be used to screen for infection as well as to confirm eradication after H. Pylori treatment. $244,245,246,247$ However, UBTs may produce a false negative result in patients who are taking PPIs, bismuth or antibiotics. It is currently recommended to withhold bismuth and antibiotics for at least 28 days and a PPI for 7-14 days prior to UBT to reduce false negative results. ${ }^{234,235,248}$ It is unknown whether H2RAs affect the sensitivity of the UBT ${ }^{249}$, although these drugs are generally stopped for 24-48 hours before the UBT.

A urease blood test, using a 13 C- bicarbonate assay also reliably detects active H. Pylori infection before and after treatment. In the presence of $\mathrm{H}$. Pylori, the ingestion of a $13 \mathrm{C}$ urea rich meal results in the production of labelled bicarbonate, which can be measured in serum. 250,251

\subsubsection{Serological test or antibody test}

Antibody testing is based upon the detection of $\mathrm{H}$. Pylori specific Ig G antibodies in serum, whole blood or urine. Antibodies to $\mathrm{H}$. Pylori can be quantitatively assessed using laboratory-based ELISA and latex agglutination techniques or qualitatively assessed using office-based serological kits.

Antibody testing is cheap, widely available and easy to perform. However, there are several factors limiting its usefulness in clinical practice. The test is less accurate when compared with other diagnostic tests. 252 The test has high sensitivity (88-94\%), but variable specificity (74-88\%) with accuracy ranging from 83 to $98 \%$. In general, office based serological kits are less accurate than laboratory-based quantitative tests. The PPV of the test is greatly influenced by the prevalence of $\mathrm{H}$. Pylori infection. ${ }^{253}$ In a population with low prevalence of $\mathrm{H}$. Pylori infection, a positive antibody test is more likely to be a false positive test. Finally, serological tests are unreliable indicators of $\mathrm{H}$. pylori status in patients who have received treatment for the infection. ${ }^{254}$ Although antibody titres fall in most patients after successful eradication, the rate and extent of the decline are highly variable and unpredictable.

\subsubsection{Fecal antigen test (FAT)}

$\mathrm{H}$. pylori infection can be diagnosed by identifying $\mathrm{H}$. Pylori specific antigens in the stool by enzyme immunoassay with the use of polyclonal or monoclonal anti-H. Pylori antibodies. ${ }^{255,256}$ The FAT is a reliable test to diagnose H. Pylori infection as well as to confirm eradication after treatment and can be used interchangeably with the UBT. Both polyclonal and monoclonal tests have excellent sensitivity, specificity, positive and negative predictive values for diagnosing infection before treatment. ${ }^{255}$ However, in the posttreatment setting, only the monoclonal test appears to have sensitivity, specificity and predictive values of greater than $90 \%$. The polyclonal test appears to have less satisfactory sensitivity and positive predictive value. ${ }^{255}$ Therefore, in the post-treatment setting, the monoclonal FAT is more reliable than the polyclonal test. The FAT may be effective in confirming eradication as early as 14 days after treatment 257 but, the general recommendation is to perform the test more than 4 weeks after treatment. ${ }^{255}$

The FAT has its own disadvantages. Like the UBT, the FAT may produce a false negative result in patients who are taking PPIs, antibiotics or bismuth. 258,259 To reduce false negative results, it is generally recommended to withhold bismuth and antibiotics for at least 4 weeks 
and a PPI for 2 weeks prior to the FAT. The FAT may produce a false positive result in patients with acute upper gastrointestinal bleeding. ${ }^{231,260}$ This may be due to cross-reactivity with blood products. Furthermore, the process of stool collection may be unpleasant to patients.

\section{References}

[1] Cave DR. Transmission and epidemiology of Helicobacter pylori. Am J Med 1996;100:12S

[2] Pounder RE, Ng D. The prevalence of Helicobacter pylori infection in different countries. Aliment Pharmacol Ther 1995;9 Suppl 2:33

[3] Everhart JE. Recent developments in the epidemiology of Helicobacter pylori. Gastroenterol Clin North Am 2000;29:559-79

[4] Dooley CP, Cohen H. The clinical significance of Campylobacter pylori. Ann Intern Med 1988;108:70

[5] Hunt RH. The role of Helicobacter pylori in pathogenesis: the spectrum of clinical outcomes. Scand J Gastroenterol Suppl 1996; 220:3-9.

[6] Steer HW. The gastro-duodenal epithelium in peptic ulceration. J Pathol 1985;146:355

[7] Tytgat, G, Langenberg, W, Rauws, E, Rietra, P. Campylobacter-like organism(CLO) in the human stomach. Gastroenterology 1985; 88:1620

[8] Sipponen P, Varis K, Fraki O, et al. Cumulative 10-year risk of symptomatic duodenal and gastric ulcer in patients with or without chronic gastritis. A clinical follow-up study of 454 outpatients. Scand J Gastroentrol 1990; 25:966

[9] Nomura A, Stemmermann GN, Chyou PH, et al. Helicobacter pylori infection and the risk of duodenal and gastric ulceration. Ann Intern Med 1994; 120:977

[10] Cullen D, Collins B, Christiansen K, et al. Long term risk of peptic ulcer disease in people with H pylori infectin- A community based study. Gastroenterology 1993; 104(suppl):A60

[11] Leoci C, Ierardi E, Chiloiro M, et al. Incidence and risk factors of duodenal ulcer. A retrospective cohort study. J Clin Gastroenterol 1995; 20:104

[12] Hopkins RJ, Girardi LS, Turney EA. Relationship between Helicobacter pylori eradication and reduced duodenal and gastric ulcer recurrence: a review. Gastroenterology 1996; 110:1244.

[13] Graham DY, Lew Gm, Klein PD, et al. Effect of treatment of Helicobacter pylori infection on the long- term recurrence of gastric or duodenal ulcer: a randomized, controlled study. Ann Intern Med 1992; 116:705.

[14] Van der Hulst RWM, Rauws EAJ, Koycu B, et al. Prevention of ulcer recurrence after eradication of Helicobacter pylori: a prospective long-term follow up study. Gastroenterology 1997; 113:1082.

[15] Graham DY, Lew Gm, Evans DG, et al. Effect of triple therapy (antibiotics plus bismuth) on duodenal ulcer healing: a randomized controlled trial. Ann Intern Med 1991; 115:266.

[16] Byrne MF, Kerrigan SW, Corcoran PA, et al. Helicobacter pylori binds von Willebrand factor and interacts with GPIb to induce platelet aggregation. Gastroenterology $2003 ; 124: 1846$. 
[17] Handlin RI. A hitchhiker's guide to the galaxy-an H. Pylori travel guides. Gastroenterology 2003; 124:1983.

[18] Marshall BJ, Warren JR. Unidentified curved bacilli in the stomach of patients with gastritis and peptic ulceration. Lancet 1984; 1:1311.

[19] Goodwin CS, Worsley BW. Microbiology of Helicobacter pylori. Gastroenterol Clin North Am 1993; 22:5.

[20] Chaput C, Ecobichon C, Cayet N, et al. Role of AmiA in the morphological transition of Helicobacter pylori and in the immune escape. PLoS pathog 2006; 2:e97.

[21] Hentschel E, Brandstatter G, Dragosics B, et al. Effect of ranitidine and amoxicillin plus metronidazole on the eradication of Helicobacter pylori and the recurrence of duodenal ulcer. N Engl J Med 1993; 328:308.

[22] Weeks DL, Eskandari S, Scott DR, Sachs G. A H+- gated urea channel: the link between Helicobacter pylori urease and gastric colonization. Science 2000; 287:482.

[23] Mobley HL. Defining Helicobacter pylori as a pathogen: strain heterogeneity and virulence. Am J Med 1996; 100:25.

[24] Logan RP. Adherence of Helicobacter pylori. Aliment Pharmacol Ther 1996; 10 Suppl 1:3.

[25] Parsonnet J. The incidence of Helicobacter pylori infection. Aliment Pharmacol Ther 1995; 9 Suppl 2:45.

[26] Torres J, Leal- Herrera Y, Perez G, et al. A Community-based seroepidemiologic study of Helicobacter pylori infection in Mexico. J Infect Dis 1998; 178:1089.

[27] Smoak BL, Kelley PW, Taylor DN. Seroprevalence of Helicobacter pylori infections in a cohort of US Army recruits. Am J Epidemiol 1994; 139:513.

[28] Everhart JE, Kruszon-Moran D, Perez GI, et al. Seroprevalence and ethnic differences in Helicobacter pylori infection among adults in the United States. J Infect Dis 2000; 181:1359.

[29] Graham DY, Klein PD, Opekun AR, et al. Effect of age on the frequency of active Campylobacter pylori infection diagnosed by the $13 \mathrm{C}$ urea breath test in normal subjects and patients with peptic ulcer disease. J Infect Dis 1988;157:777

[30] Imai T, Kubo T, Watanabe H. Chronic gastritis in Japanese with reference to high incidence of gastric carcinoma. J Natl Cancer Inst 1971;47:179

[31] Dwyer B, Kaldor J, Tee W, et al. Antibody response to Campylobacter pylori in diverse ethnic groups. Scand J Infect Dis 1988;20:349

[32] Mitchell HM, Bohane TD, Berkowicz J, et al. Antibody to Campylobacetr pylori in families of index children with gastrointestinal illness due to $\mathrm{C}$ pylori [Letter]. Lancet 1987; 2:681.

[33] Drumm B, Perez-Perez GI, Blaster MJ, et al. Intrafamilial clustering of Helicobacter pylori infection. N Engl J Med 1990;322:359

[34] Malaty HM, Graham DY, Klein PD, et al. Transmission of Helicobacter pylori infection. Studies in families of healthy individuals. Scand J Gastroenterol 1991; 26:927.

[35] Perez-Perez GI, Taylor DN, Bodhidatta L, et al. Seroprevalence of Helicobacter pylori infections in Thialand. J Infect Dis 1990;161:1237 
[36] Rauws EAJ, Langerberg W, Oudbier J, et al. Familial clustering of peptic ulcer disease colonized with C. Pylori of the same DNA composition [Abstract]. Gastroenterology 1989;96:409

[37] Kim F, Mobley HLT, Burken M, Morris JG. Molecular epidemiology of Campylobacter pylori infection in a chronic care facility [Abstract]. Gastroenterology 1989;96:256

[38] Hunt RH, Sumanac K, Huang JQ. Review article: should we kill or should we save Helicobacter pylori? Aliment Pharmacol Ther 2001; 15 Suppl 1:51-59.

[39] Webb PM, Knight T, Greaves S, et al. Relation between infection with Helicobacter pylori and living conditions in childhood: evidence for person to person transmission in early life. BMJ 1994; 308:750.

[40] Kivi M, Johansson AL, Reilly M, Tindberg Y. Helicobacter pylori status in family members as risk factors for infection in children. Epidemiol Infect 2005; 133:645.

[41] Mendall MA, Goggin PM, Molineaux N, et al. Childhood living conditions and Helicobacter pylori seropositivity in adult life. Lancet 1992;339:896

[42] Malaty HM, Engstrand L, Pedersen NL, Graham DY. Helicobacter pylori infection: genetic and environmental influences. A study of twins. Ann Intern Med 1994; 120:982.

[43] Riccardi VM, Rotter JI. Familial Helicobacter pylori infection. Societal factors, human genetics, and bacterial genetics. Ann Intern Med 1994; 120:1043.

[44] Graham DY, Malaty HM, Evans DG, et al. Epidemiology of Helicobacter pylori in an asymptomatic population in the United States. Effect of age, race, and socioeconomic status. Gastroenterology 1991; 100:1495.

[45] Mégraud F. Transmission of Helicobacter pylori: faecal-oral versus oral-oral route. Aliment Pharmacol Ther 1995; 9 Suppl 2:85.

[46] Perry S, de la Luz Sanchez M, Yang S, et al. Gastroenteritis and transmission of Helicobacter pylori infection in households. Emerg Infect Dis 2006; 12:1701.

[47] Fox JG. Non-human reservoirs of Helicobacter pylori. Aliment Pharmacol Ther 1995; 9 Suppl 2:93

[48] Handt LK, Fox JG, Dewhirst FE, et al. Helicobacter pylori isolated from the domestic cat: public health implications. Infect Immun 1994; 62:2367.

[49] Dore MP, Sepulveda AR, El-Zimaity H, et al. Isolation of Helicobacter pylori from sheep-implications for transmission to humans. Am J Gastroenterol 2001; 96:1396

[50] Hulten K, Han SW, Enroth H, et al. Helicobacter pylori in the drinking water in Peru. Gastroenterology 1996; 110:1031.

[51] Bellack NR, Koehoorn MW, MacNab YC, Morshed MG. A conceptual model of water's role as a reservoir in Helicobacter pylori transmission: a review of the evidence. Epidemiol Infect 2006; 134:439

[52] Queralt N, Bartolomé R, Araujo R. Detection of Helicobacter pylori DNA in human faeces and water with different levels of faecal pollution in the north-east of Spain. J Appl Microbiol 2005; 98:889.

[53] Goodman KJ, Correa P, Tenganá Aux HJ, et al. Helicobacter pylori infection in the Colombian Andes: a population-based study of transmission pathways. Am J Epidemiol 1996; 144:290. 
[54] Thomas JE, Gibson GR, Darboe MK, et al. Isolation of Helicobacter pylori from human faeces. Lancet 1992; 340:1194.

[55] Kelly SM, Pitcher MC, Farmery SM, et al. Isolation of Helicobacter pylori from feces of patients with dyspepsia in the United Kingdom. Gastroenterology 1994;107:1671

[56] Hardo PG, Tugnait A, Hassan F, et al. Helicobacter pylori infection and dental care. Gut 1995; $37: 44$

[57] Axon AT. Review article: is Helicobacter pylori transmitted by the gastro-oral route? Aliment Pharmacol Ther 1995; 9:585

[58] Tytgat GN. Endoscopic transmission of Helicobacter pylori. Aliment Pharmacol Ther 1995; 9 Suppl 2:105.

[59] Reid J, Taylor TV, Holt S, et al. Benign gastric ulceration in pernicious anemia. Dig Dis Sci 1980;25:148

[60] Peura DA. Ulcerogenesis: integrating the roles of Helicobacter pylori and acid secretion in duodenal ulcer. Am J Gastroenterol 1997; 92:8S.

[61] el-Omar E, Penman I, Dorrian CA, et al. Eradicating Helicobacter pylori infection lowers gastrin mediated acid secretion by two thirds in patients with duodenal ulcer. Gut 1993; 34:1060.

[62] Peterson WL, Barnett CC, Evans DJ Jr, et al. Acid secretion and serum gastrin in normal subjects and patients with duodenal ulcer: the role of Helicobacter pylori. Am J Gastroenterol 1993; 88:2038.

[63] Calam, J. The somatostatin-gastrin link of Helicobacter pylori infection. Ann Med 1995; 27:569.

[64] Moss SF, Legon S, Bishop AE, et al. Effect of Helicobacter pylori on gastric somatostatin in duodenal ulcer disease. Lancet 1992; 340:930

[65] Beales I, Calam J, Post L, et al. Effect of tumor necrosis factor alpha and interleukin 8 on somatostatin release from canine fundic D cells. Gastroenterology 1997;112:136

[66] Graham, DY. Helicobacter pylori and perturbations in acid secretion: the end of the beginning. Gastroenterology 1996; 110:1647.

[67] Moss SF, Calam J. Acid secretion and sensitivity to gastrin in patients with duodenal ulcer: effect of eradication of Helicobacter pylori. Gut 1993; 34:888

[68] Wyatt JI, Rathbone BJ, Dixon MF, Heatley RV. Campylobacter pyloridis and acid induced gastric metaplasia in the pathogenesis of duodenitis. J Clin Pathol 1987; 40:841.

[69] Hamlet, A, Thoreson, AC, Nilsson, O, et al. Duodenal Helicobacter pylori infection differs in cagA genotype between asymptomatic subjects and patients with duodenal ulcers. Gastroenterology 1999; 116:259.

[70] el-Omar EM, Penman ID, Ardill JES, Chittajallu RS, Howie C, McColl KEL. Helicobacter pylori infection and abnormalities of acid secretion in patients with duodenal ulcer disease. Gastroenterology 1995;109:681-691

[71] Gillen D, el-Omar EM, Wirz AA, Ardill JES, McColl KEL. The acid response to gastrin distinguishes duodenal ulcer patients from Helicobacter pylori-infected healthy subjects. Gastroenterology 1998;114:50-57 
[72] Borsch G, Schmidt G, Wegener M, et al. Campylobacter pylori: prospective analysis of clinical and histological factors associated with colonization of the upper gastrointestinal tract. Eur J Clin Invest 1988;18:133

[73] Fitzgibbons PL, Dooley CP, Cohen H, Appleman MD. Prevalence of gastric metaplasia, inflammation, and Campylobacter pylori in the duodenum of members of a normal population. Am J Clin Pathol 1988;90:711

[74] Hazell SL, Hennessy WB, Borody TJ, et al. Campylobacter pyloridis gastritis. II. Distribution of bacteria and associated inflammation in the gastroduodenal environment. Am J Gastroenterol 1987;82:297

[75] Kreuning J, Bosman FT, Kuiper G, et al. Gastric and duodenal mucosa in "healthy" individuals: an endoscopic and histopathological study of 50 volunteers. J Clin Pathol 1978; 31:69.

[76] Savarino V, Mela GS, Zentilin P, et al. 24 hour gastric PH and extent of duodenal gastric metaplasia in Helicobacter pylori-positive patients. Gastroenterology 1997; 113:741

[77] Isenberg J, McQuaid K, Laine L, Walsh J. Acid-Peptic Disorders. In: Textbook of Gastroenterology, Second Edition, Yamada, T (Ed), JP, Lippincott, Philadelphia 1995. p.1347.

[78] Hogan DL, Rapier RC, Dreilinger A, et al. Duodenal bicarbonate secretion: eradication of Helicobacter pylori and duodenal structure and function in humans. Gastroenterology 1996; 110:705.

[79] Konturek PC, Ernst H, Konturek SJ, et al. Mucosal expression and luminal release of epidermal and transforming growth factors in patients with duodenal ulcer before and after eradication of Helicobacter pylori. Gut 1997; 40:463.

[80] Weel JF, van der Hulst RW, Gerrits Y, et al. The interrelationship between cytotoxinassociated gene A, vacuolating cytotoxin, and Helicobacter pylori-related diseases. J Infect Dis 1996; 173:1171.

[81] Lu H, Hsu PI, Graham DY, Yamaoka Y. Duodenal ulcer promoting gene of Helicobacter pylori. Gastroenterology 2005; 128:833

[82] Yamaoka Y. Roles of the plasticity regions of Helicobacter pylori in gastroduodenal pathogenesis. J Med Microbiol 2008; 57:545.

[83] Kurata JH, Nogawa AN. Meta-analysis of risk factors for peptic ulcer: nonsteroidal antiinflammatory drugs, Helicobacter pylori, and smoking. J Clin Gastroenterol $1997 ; 24: 2$

[84] Elizalde JI, Gómez J, Panés J, et al. Platelet activation In mice and human Helicobacter pylori infection. J Clin Invest 1997; 100:996.

[85] El-Omar EM, Oien K, El Nujumi A, et al. Helicobacter pylori infection and chronic gastric acid hyposecretion. Gastroenterology 113 (1997), pp. 15-24.

[86] Ernst PB, Peura DA, Crowe SE. The translation of Helicobacter pylori basic research to patient care. Gastroenterology 2006; 130:188-199.

[87] Amieva MR, El-Omar EM. Host-Bacterial interactions in Helicobacter pylori infection. Gastroenterology 2008; 134:306-323

[88] Merrell DS, Goodrich ML, Otto G, Tompkins LS, Falkow S. pH-regulated gene expression of the gastric pathogen Helicobacter pylori. Infect Immun 71 (2003), pp. 3529-3539. 
[89] Schreiber S, Konradt M, Groll C, et al. The spatial orientation of Helicobacter pylori in the gastric mucus. Proc Natl Acad Sci USA 101 (2004), pp. 5024-5029

[90] Hessey SJ, Spencer J, Wyatt JI, et al. Bacterial adhesion and disease activity in Helicobacter associated chronic gastritis. Gut 31 (1990), pp. 134-138.

[91] Mobley HL, Hu LT, Foxall PA. Helicobacter pylori urease: properties and role in pathogenesis. Scand J Gastroenterol 26 (1991) (Suppl 187), pp. 39-46.

[92] Phadnis SH, Parlow MH, Levy M, Ilver D, et al. Surface localization of a Helicobacter pylori urease and heat shock protein homolog requires bacterial lysis. Infect Immun 64 (1995), pp. 905-912.

[93] Scott DR, Weeks D, Hong C, Postius S, Melchers K, Sachs G. The role of internal urease in acid resistance of Helicobacter pylori. Gastroenterology 114 (1998), pp. 58-70

[94] Scott DR, Marcus EA, Weeks DL, Sachs G. Mechanisms of acid resistance due to the urease system of Helicobacter pylori. Gastroenterology 123 (2002), pp. 187-195.

[95] Ilver D, Arnqvist A, Ogren J, et al. Helicobacter pylori adhesin binding fucosylated histo-blood group antigens revealed by retagging. Science 1998; 279:373.

[96] Rad R, Gerhard M, Lang R, Schoniger M, et al. The Helicobacter pylori blood group antigen-binding adhesin facilitates bacterial colonization and augments a nonspecific immune response. J Immunol 168 (2002), pp. 3033-3041.

[97] Prinz C, Schoniger M, Rad R, et al. Key importance of the Helicobacter pylori adherence factor blood group antigen binding adhesin during chronic gastric inflammation. Cancer Res 61 (2001), pp. 1903-1909.

[98] Yamaoka Y, Kwon DH, Graham DY. A M(r) 34,000 proinflammatory outer membrane protein (oipA) of Helicobacter pylori. Proc Natl Acad Sci U S A 2000; 97:7533.

[99] Mahdavi J, Sondén B, Hurtig M, et al. Helicobacter pylori SabA adhesin in persistent infection and chronic inflammation. Science 2002; 297:573.

[100] Yahiro K, Wada A, Nakayama M, et al. Protein-tyrosine phosphatase alpha, RPTP alpha, is a Helicobacter pylori VacA receptor. J Biol Chem 278 (2003), pp. 1918319189.

[101] de Jonge R, Durrani Z, Rijpkema SG, et al. Role of the Helicobacter pylori outermembrane proteins AlpA and AlpB in colonization of the guinea pig stomach. J Med Microbiol 53 (2004), pp. 375-379.

[102] Aspholm-Hurtig M, Dailide G, Lahmann M, et al. Functional adaptation of BabA, the $\mathrm{H}$ pylori ABO blood group antigen binding adhesion. Science 305 (2004), pp. 519522.

[103] Dossumbekova A, Prinz C, Mages J, et al. Helicobacter pylori HopH (OipA) and bacterial pathogenicity: genetic and functional genomic analysis of hopH gene polymorphisms. J Infect Dis 194 (2006), pp. 1346-1355.

[104] Solnick JV, Hansen LM, Salama NR, et al. Modification of Helicobacter pylori outer membrane protein expression during experimental infection of rhesus macaques. Proc Natl Acad Sci U S A 101 (2004), pp. 2106-2111

[105] de Jonge R, Pot RG, Loffeld RJ, et al. The functional status of the Helicobacter pylori sabB adhesin gene as a putative marker for disease outcome. Helicobacter 9 (2004), pp. 158-164. 
[106] Boren T, Falk P, Roth KA, Larson G, Normark S. Attachment of Helicobacter pylori to human gastric epithelium mediated by blood group antigens. Science 262 (1993), pp. 1892-1895.

[107] Falk P, Roth KA, Boren T, et al. An in vitro adherence assay reveals that Helicobacter pylori exhibits cell lineage-specific tropism in the human gastric epithelium. Proc Natl Acad Sci U S A 90 (1993), pp. 2035-2039.

[108] Clyne M, Drumm B. Absence of effect of Lewis A and Lewis B expression on adherence of Helicobacter pylori to human gastric cells. Gastroenterology 113 (1997), pp. 72-80.

[109] Niv Y, Fraser G, Delpre G, et al. Helicobacter pylori infection and blood groups. Am J Gastroenterol 91 (1996), pp. 101-104.

[110] Fan XJ, Crowe SE, Behar S, et al. The effect of class II MHC expression on adherence of Helicobacter pylori and induction of apoptosis in gastric epithelial cells: a mechanism for Th1 cell-mediated damage. J Exp Med 187 (1998), pp. 1659-1669.

[111] Fan X, Gunasena H, Cheng Z, et al. Helicobacter pylori urease binds to class II MHC on gastric epithelial cells and induces their apoptosis. J Immunol 165 (2000), pp. 1918-1924.

[112] Medzhitov R. Toll-like receptors and innate immunity. Nat Rev Immunol 1 (2001), pp. 135-145.

[113] Smith MF Jr, Mitchell A, Li G, et al. TLR2 and TLR5, but not TLR4, are required for Helicobacter pylori-induced NF-kappa B activation and chemokine expression by epithelial cells. J Biol Chem 278 (2003), pp. 32552-32560.

[114] Su B, Ceponis PJ, Lebel S, Huynh H, Sherman P.M. Helicobacter pylori activates Tolllike receptor 4 expression in gastrointestinal epithelial cells. Infect Immun 71 (2003), pp. 3496-3502.

[115] Ishihara S, Rumi MA, Kadowaki Y, et al. Essential role of MD-2 in TLR4-dependent signaling during Helicobacter pylori-associated gastritis. J Immunol 173 (2004), pp. 1406-1416.

[116] Clyne M, Dillon P, Daly S, et al. Helicobacter pylori interacts with the human singledomain trefoil protein TFF1. Proc Natl Acad Sci U S A 101 (2004), pp. 7409-7414.

[117] O'Brien DP, Israel DA, Krishna U, et al. The role of decay-accelerating factor as a receptor for Helicobacter pylori and a mediator of gastric inflammation. J Biol Chem 281 (2006), pp. 13317-13323.

[118] Leunk RD, Johnson PT, David BC, et al. Cytotoxic activity in broth-culture filtrates of Campylobacter pylori. J Med Microbiol 26 (1988), pp. 93-99.

[119] Nomura AM, Perez-Perez GI, Lee J, et al. Relation between Helicobacter pylori cagA status and risk of peptic ulcer disease. Am J Epidemiol 2002; 155:1054-1059.

[120] Blaser MJ. Role of vacA and the cagA locus of Helicobacter pylori in human disease. Aliment Pharmacol Ther 1996; 10 Suppl 1:73.

[121] Figura N. Helicobacter pylori exotoxins and gastroduodenal diseases associated with cytotoxic strain infection. Aliment Pharmacol Ther 1996; 10 Suppl 1:79.

[122] Iwamoto H, Czajkowsky DM, Cover TL, et al. VacA from Helicobacter pylori: a hexameric chloride channel. FEBS Lett 450 (1999), pp. 101-104. 
[123] Atherton JC, Cao P, Peek RM Jr. Mosaicism in vacuolating cytotoxin alleles of Helicobacter pylori: Association of specific vacA types with cytotoxin production and peptic ulceration. J Biol Chem 270 (1995), pp. 17771-17777.

[124] Ilver D, Barone S, Mercati D, et al. Helicobacter pylori toxin VacA is transferred to host cells via a novel contact-dependent mechanism. Cell Microbiol 6 (2004), pp. 167174.

[125] Blaser MJ, Atherton JC. Helicobacter pylori persistence: biology and disease. J Clin Invest 113 (2004), pp. 321-333.

[126] Cover TL. The vacuolating cytotoxin of Helicobacter pylori. Mol Microbiol 20 (1996), pp. 241-246.

[127] Yamasaki E, Wada A, Kumatori A, et al. Helicobacter pylori vacuolating cytotoxin induces activation of the proapoptotic proteins Bax and Bak, leading to cytochrome c release and cell death, independent of vacuolation. J Biol Chem 281 (2006), pp. 11250-11259.

[128] Willhite DC, Blanke SR. Helicobacter pylori vacuolating cytotoxin enters cells, localizes to the mitochondria, and induces mitochondrial membrane permeability changes correlated to toxin channel activity. Cell Microbiol 6 (2004), pp. 143-154.

[129] Papini E, Satin B, Norais N, et al. Selective increase of the permeability of polarized epithelial cell monolayers by Helicobacter pylori vacuolating toxin. J Clin Invest 102 (1998), pp. 813-820.

[130] Gebert B, Fischer W, Weiss E, et al. Helicobacter pylori vacuolating cytotoxin inhibits T lymphocyte activation. Science 301 (2003), pp. 1099-1102.

[131] Blaser MJ, Perez-Perez GI, Kleanthous H, et al. Infection with Helicobacter pylori strains possessing cagA is associated with an increased risk of developing adenocarcinoma of the stomach. Cancer Res 55 (1995), pp. 2111-2115.

[132] Wu AH, Crabtree JE, Bernstein L, et al. Role of Helicobacter pylori CagA+ strains and risk of adenocarcinoma of the stomach and esophagus. Int J Cancer 103 (2003), pp. 815-821.

[133] Huang JQ, Zheng GF, Sumanac K, et al. Meta-analysis of the relationship between cagA seropositivity and gastric cancer. Gastroenterology 125 (2003), pp. 1636-1644.

[134] Peek RM Jr, Miller GG, Tham KT, et al. Heightened inflammatory response and cytokine expression in vivo to cagA+ Helicobacter pylori strains. Lab Invest 73 (1995), pp. 760-770.

[135] Peek RM Jr, Moss SF, Tham KT, et al. Helicobacter pylori cagA+ strains and dissociation of gastric epithelial cell proliferation from apoptosis. J Natl Cancer Inst 89 (1997), pp. 863-868.

[136] Figura N, Vindigni C, Covacci A, et al. cagA positive and negative Helicobacter pylori strains are simultaneously present in the stomach of most patients with non-ulcer dyspepsia: relevance to histological damage. Gut 42 (1998), pp. 772-778.

[137] Naumann M, Crabtree JE. Helicobacter pylori-induced epithelial cell signalling in gastric carcinogenesis. Trends Microbiol 12 (2004), pp. 29-36.

[138] Elliott SN, Ernst PB, Kelly CP. The year in Helicobacter pylori 2001: molecular inflammation. Curr Opin Gastroenterol 17 (2002), pp. s12-s18. 
[139] Israel DA, Salama N, Arnold CN, Moss SF, et al. Helicobacter pylori strain-specific differences in genetic content, identified by microarray, influence host inflammatory responses. J Clin Invest 107 (2001), pp. 611-620.

[140] Brandt S, Kwok T, Hartig R, et al. NF-kB activation and potentiation of proinflammatory responses by the Helicobacter pylori CagA protein. Proc Natl Acad Sci U S A 102 (2005), pp. 9300-9305.

[141] Kim SY, Lee YC, Kim HK, et al. Helicobacter pylori CagA transfection of gastric epithelial cells induces interleukin-8. Cell Microbiol 8 (2006), pp. 97-106.

[142] Yamaoka Y, Kudo T, Lu H, Casola A, Braiser AR, Graham DY. Role of interferonstimulated responsive element-like element in interleukin-8 promoter in Helicobacter pylori infection. Gastroenterology 2004; 126:1030-1043.

[143] Viala J, Chaput C, Boneca IG, Cardona A, et al. Nod1 responds to peptidoglycan delivered by the Helicobacter pylori cag pathogenicity island. Nat Immunol 2004; 5:1166-1174.

[144] Stein M, Bagnoli F, Halenbeck R, et al. c-Src/Lyn kinases activate Helicobacter pylori CagA through tyrosine phosphorylation of the EPIYA motifs. Mol Microbiol 43 (2002), pp. 971-980

[145] Stein M, Rappuoli R, Covacci A. Tyrosine phosphorylation of the Helicobacter pylori CagA antigen after cag-driven host cell translocation. Proc Natl Acad Sci U S A 97 (2000), pp. 1263-1268.

[146] Selbach M, Moese S, Hauck CR, Meyer TF, Backert S. Src is the kinase of the Helicobacter pylori CagA protein in vitro and in vivo. J Biol Chem 277 (2002), pp. 6775-6778.

[147] Tsutsumi R, Higashi H, Higuchi M, Okada M, Hatakeyama M. Attenuation of Helicobacter pylori CagA x SHP-2 signaling by interaction between CagA and Cterminal Src kinase. J Biol Chem 278 (2003), pp. 3664-3670.

[148] Chang YJ,Wu MS, Lin JT et al. Mechanisms for Helicobacter pylori CagA-induced cyclin D1 expression that affect cell cycle. Cell Microbiol 8 (2006), pp. 1740-1752.

[149] Hirata Y, Maeda S, Mitsuno Y, et al. Helicobacter pylori CagA protein activates serum response element-driven transcription independently of tyrosine phosphorylation. Gastroenterology 123 (2002), pp. 1962-1971.

[150] Amieva MR, Vogelmann R, Covacci A, et al. Disruption of the epithelial apicaljunctional complex by Helicobacter pylori CagA. Science 300 (2003), pp. 1430-1434.

[151] Murata-Kamiya N, Kurashima Y, Teishikata Y, et al. Helicobacter pylori CagA interacts with E-cadherin and deregulates the $\beta$-catenin signal that promotes intestinal transdifferentiation in gastric epithelial cells. Oncogene 26 (2007), pp. 4617-4626.

[152] Bagnoli F, Buti L, Tompkins L, et al. Helicobacter pylori CagA induces a transition from polarized to invasive phenotypes in MDCK cells. Proc Natl Acad Sci U S A 102 (2005), pp. 16339-16344.

[153] van Doorn LJ, Figueiredo C, Sanna R, et al. Clinical relevance of the cagA, vacA, and iceA status of Helicobacter pylori. Gastroenterology 1998; 115:58 
[154] Peek RM Jr, Thompson SA, Donahue JP, et al. Adherence to gastric epithelial cells induces expression of a Helicobacter pylori gene, iceA, that is associated with clinical outcome. Proc Assoc Am Physicians 1998; 110:531.

[155] Nogueira C, Figueiredo C, Carneiro F, et al. Helicobacter pylori genotypes may determine gastric histopathology. Am J Pathol 2001; 158:647.

[156] Gerhard M, Lehn N, Neumayer N, et al. Clinical relevance of the Helicobacter pylori gene for blood-group antigen-binding adhesin. Proc Natl Acad Sci U S A 1999; 96:12778.

[157] Yamaoka Y, Kikuchi S, el-Zimaity HM, et al. Importance of Helicobacter pylori oipA in clinical presentation, gastric inflammation, and mucosal interleukin 8 production. Gastroenterology 2002; 123:414.

[158] Nilius M, Malfertheiner P. Helicobacter pylori enzymes. Aliment Pharmacol Ther 1996; 10 Suppl 1:65.

[159] Wex T, Treiber G, Nilius M, Vieth M, Roessner A, Malfertheiner P. Helicobacter pylorimediated gastritis induces local downregulation of secretory leukocyte protease inhibitor in the antrum. Infect Immun 72 (2004), pp. 2383-2385.

[160] Gobert AP, McGee DJ, Akhtar M, Mendz GL, Newton JC, Cheng Y, Mobley HL, Wilson KT. Helicobacter pylori arginase inhibits nitric oxide production by eukaryotic cells: a strategy for bacterial survival. Proc Natl Acad Sci U S A 98 (2001), pp. 13844-13849.

[161] Byrd JC, Yunker CK, Xu QS, Sternberg L.R, Bresalier RS. Inhibition of gastric mucin synthesis by Helicobacter pylori. Gastroenterology 118 (2000), pp. 1072-1079.

[162] Allen LA, Schlesinger LS, Kang B. Virulent strains of Helicobacter pylori demonstrate delayed phagocytosis and stimulate homotypic phagosome fusion in macrophages. J Exp Med 191 (2000), pp. 115-128.

[163] Gewirtz AT, Yu Y, Krishna US, et al., Helicobacter pylori flagellin evades toll-like receptor 5-mediated innate immunity. J Infect Dis 189 (2004), pp. 1914-1920.

[164] Moran AP, Knirel YA, Senchenkova SN, et al. Phenotypic variation in molecular mimicry between Helicobacter pylori lipopolysaccharides and human gastric epithelial cell surface glycoforms: Acid-induced phase variation in Lewis(x) and Lewis(y) expression by H pylori lipopolysaccharides. J Biol Chem 277 (2002), pp. 5785-5795.

[165] Karttunen R, Karttunen T, Ekre HP, MacDonald TT. Interferon gamma and interleukin 4 secreting cells in the gastric antrum in Helicobacter pylori positive and negative gastritis. Gut 36 (1995), pp. 341-345.

[166] Lindholm C, Quiding-Jarbrink M, Lonroth H, Hamlet A, Svennerholm AM. Local cytokine response in Helicobacter pylori-infected subjects. Infect Immun 66 (1998), pp. 5964-5971.

[167] D'Elios MM, Manghetti M, Almerigogna F, Amedei A, et al. Different cytokine profile and antigen-specificity repertoire in Helicobacter pylori-specific $\mathrm{T}$ cell clones from the antrum of chronic gastritis patients with or without peptic ulcer. Eur J Immunol 27 (1997), pp. 1751-1755. 
[168] El-Omar EM, Rabkin CS, Gammon MD et al. Increased risk of noncardia gastric cancer associated with proinflammatory cytokine gene polymorphisms. Gastroenterology 124 (2003), pp. 1193-1201.

[169] El-Omar EM, Carrington M, Chow WH et al., Interleukin-1 polymorphisms associated with increased risk of gastric cancer. Nature 404 (2000), pp. 398-402.

[170] El-Omar EM, The importance of interleukin $1 \beta$ in Helicobacter pylori associated disease. Gut 48 (2001), pp. 743-747.

[171] Chaturvedi R, Asim M, Bussiere FI, Singh K, Casero RAJ, Peek RM, et al. Spermine oxidase as the link between $\mathrm{H}$ pylori cagA and gastric carcinogenesis. Gastroenterology. 2006;130:A60

[172] Amieva MR, Salama NR, Tompkins LS, Falkow S. Helicobacter pylori enter and survive within multivesicular vacuoles of epithelial cells. Cell Microbiol. 2002;4:677-690

[173] Semino-Mora C, Doi SQ, Marty A, Simko V, Carlstedt I, Dubois A. Intracellular and interstitial expression of Helicobacter pylori virulence genes in gastric precancerous intestinal metaplasia and adenocarcinoma. J Infect Dis. 2003;187:1165-1177

[174] Necchi V, Candusso ME, Tava F, Luinetti O, Ventura U, Fiocca R, et al. Intracellular, intercellular, and stromal invasion of gastric mucosa, preneoplastic lesions, and cancer by Helicobacter pylori. Gastroenterology. 2007;132:1009-1023.

[175] Segal ED , Cha J , Lo J , Falkow S , Tompkins LS . Altered states (involvement of phosphorylated CagA in the induction of host cellular growth changes by Helicobacter pylori). Proc Natl Acad Sci U S A . 1999;96:14559-14564

[176] Peek RM . IV. Helicobacter pylori strain-specific activation of signal transduction cascades related to gastric inflammation. Am J Physiol Gastrointest Liver Physiol . 2001;280:G525-G530

[177] Moss SF, Sordillo EM, Abdalla AM, Makarov V, Hanzely Z, Perez-Perez GI, et al. Increased gastric epithelial cell apoptosis associated with colonization with cagA + Helicobacter pylori strains. Cancer Res 2001;61:1406-1411

[178] Chiou CC , Chan CC , Sheu DL , Chen KT , Li YS , Chan EC . Helicobacter pylori infection induced alteration of gene expression in human gastric cells. Gut 2001;48:598-604.

[179] Cox JM , Clayton CL , Tomita T , Wallace DM , Robinson PA , Crabtree JE . cDNA array analysis of cag pathogenicity island-associated Helicobacter pylori epithelial cell response genes. Infect Immun 2001;69:6970-6980

[180] Guillemin K, Salama NR , Tompkins LS , Falkow S . Cag pathogenicity island-specific responses of gastric epithelial cells to Helicobacter pylori infection. Proc Natl Acad Sci U S A . 2002;99:15136-15141

[181] Sepulveda AR , Tao H , Carloni E , Sepulveda J , Graham DY , Peterson LE . Screening of gene expression profiles in gastric epithelial cells induced by Helicobacter pylori using microarray analysis. Aliment Pharmacol Ther. 2002;16(Suppl 2):145-157

[182] Yasumoto K , Okamoto S , Mukaida N , Murakami S , Mai M , Matsushima K . Tumor necrosis factor a and interferon $\gamma$ synergistically induce interleukin 8 production in a human gastric cancer cell line through acting concurrently on AP-1 and NF- 
kappaB-like binding sites of the interleukin 8 gene . J Biol Chem. 1992;267:2250622511

[183] Aihara M, Tsuchimoto D, Takizawa H, Azuma A, Wakebe H, Ohmoto Y, et al. Mechanisms involved in Helicobacter pylori-induced interleukin-8 production by a gastric cancer cell line, MKN45 . Infect Immun. 1997;65:3218-3224

[184] Maeda S, Yoshida H, Ogura K, Mitsuno Y, Hirata Y, Yamaji Y, et al. H. pylori activates NF-kappaB through a signaling pathway involving IkappaB kinases, NF-kappaBinducing kinase, TRAF2, and TRAF6 in gastric cancer cells . Gastroenterology 2000;119:97-108

[185] Keates S , Keates AC , Warny M , Peek RM , Murray PG , Kelly CP . Differential activation of mitogen-activated protein kinases in AGS gastric epithelial cells by cag+ and cag- Helicobacter pylori. J Immunol.1999;163:5552-5559

[186] Naumann M, Wessler S, Bartsch C, Wieland B, Covacci A, Haas R, et al. Activation of activator protein 1 and stress response kinases in epithelial cells colonized by Helicobacter pylori encoding the cag pathogenicity island. J Biol Chem. 1999;274:31655-31662

[187] Hawley AT, Ryan KA, Ravichandran KS, Ernst PB. Complement-mediated phagocytosis of Helicobacter pylori-infected gastric epithelial cells: a novel mechanism for sensing luminal bacterial infection. Gastroenterology (in press).

[188] Satin B, Del Giudice G, Della Bianca V, Dusi S, Laudanna C, Tonello F, et al. The neutrophil-activating protein (HP-NAP) of Helicobacter pylori is a protective antigen and a major virulence factor. J Exp Med. 2000;191:1467-1476

[189] Harris PR , Mobley HLT , Perez-Perez GI , Blaser MJ , Smith PD . Helicobacter pylori urease is a potent stimulus of mononuclear phagocyte activation and inflammatory cytokine production. Gastroenterology. 1996;111:419-425

[190] Gobert AP, Bambou JC, Werts C, Balloy V, Chignard M, Moran AP, et al. Helicobacter pylori heat shock protein 60 mediates interleukin-6 production by macrophages via a toll-like receptor (TLR)-2-, TLR-4-, and myeloid differentiation factor 88independent mechanism . J Biol Chem . 2004;279:245-250

[191] Eck M, Schmausser B, Scheller K, Toksoy A, Kraus M, Menzel T, et al. CXC chemokines Gro(alpha)/IL-8 and IP-10/MIG in Helicobacter pylori gastritis . Clin Exp Immunol. 2000;122:192-199

[192] Haeberle HA, Kubin M, Bamford KB, Garofalo R, Graham DY, El Zaatari F, et al. Differential stimulation of interleukin-12 (IL-12) and IL-10 by live and killed Helicobacter pylori in vitro and association of IL-12 production with gamma interferon-producing $\mathrm{T}$ cells in the human gastric mucosa. Infect Immun. 1997;65:4229-4235

[193] Tomita T, Jackson AM, Hida N, Hayat M, Dixon MF, Shimoyama T, et al. Expression of interleukin-18, a Th1 cytokine, in human gastric mucosa is increased in Helicobacter pylori infection . J Infect Dis. 2001;183:620-627

[194] Ernst PB, Jin Y, Reyes VE, Crowe SE. The role of the local immune response in the pathogenesis of peptic ulcer formation. Scand J Gastroenterol Suppl 1994; 205:22.

[195] Di Tommaso A, Xiang Z, Bugnoli M, et al. Helicobacter pylori-specific CD4+ T-cell clones from peripheral blood and gastric biopsies. Infect Immun 1995; 63:1102. 
[196] Bamford K.B,Fan X and. Crowe S.E et al., Lymphocytes in the human gastric mucosa during Helicobacter pylori have a T helper cell 1 phenotype. Gastroenterology 114 (1998), pp. 482-492.

[197] Hida N, Shimoyama T, Neville P, Dixon MF, Axon AT, Shimoyama T, et al. Increased expression of IL-10 and IL-12 (p40) mRNA in Helicobacter pylori infected gastric mucosa (relation to bacterial cag status and peptic ulceration). J Clin Pathol 1999;52:658-664

[198] Ceponis PJ, McKay DM , Menaker RJ , Galindo-Mata E , Jones NL . Helicobacter pylori infection interferes with epithelial Stat6-mediated interleukin-4 signal transduction independent of cagA, cagE, or VacA. J Immunol. 2003;171:2035-2041

[199] Lehmann FS, Terracciano L, Carena I, Baeriswyl C, Drewe J, Tornillo L, et al. In situ correlation of cytokine secretion and apoptosis in Helicobacter pylori-associated gastritis. Am J Physiol Gastrointest Liver Physiol . 2002;283:G481-G488

[200] Wang J, Fan XJ, Lindholm C, Bennet M, O'Connell J, Shanahan F, et al. Helicobacter pylori modulates lymphoepithelial cell interactions leading to epithelial cell damage through Fas/Fas Ligand interactions. Infect Immun. 2000;68:4303-4311

[201] Valnes K , Brandtzaeg P , Elgjo K , Stave R . Quantitative distribution of immunoglobulin-producing cells in gastric mucosa (relation to chronic gastritis and glandular atrophy). Gut 1986;27:505-514

[202] Kosunen, TU. Antibody titres in Helicobacter pylori infection: implications in the follow-up of antimicrobial therapy. Ann Med 1995; 27:605.

[203] Berstad AE , Brandtzaeg P , Stave R , Halstensen TS . Epithelium related deposition of activated complement in Helicobacter pylori associated gastritis. Gut 1997;40:196203

[204] Negrini R, Lisato L, Zanella I, Cavazzini L, Gullini S, Villanacci V, et al. Helicobacter pylori infection induces antibodies cross-reacting with human gastric mucosa . Gastroenterology 1991;101:437-445

[205] Appelmelk BJ, Simoons-Smit I, Negrini R, Moran AP, Aspinall GO, Forte JG, et al. Potential role of molecular mimicry between Helicobacter pylori lipopolysaccharide and host Lewis blood group antigens in autoimmunity . Infect Immun 1996;64:2031-2040

[206] Chey, WD, Wong, BC, Practice Parameters Committee of the American College of Gastroenterology. American College of Gastroenterology guideline on the management of Helicobacter pylori infection. Am J Gastroenterol 2007; 102:18081816.

[207] Malfertheiner, P, Megraud, F, O'Morain, C, et al. Current concepts in the management of Helicobacter pylori infection: the Maastricht III Consensus Report. Gut 2007; $56: 772$

[208] Sharma VK, Sahai AV, Corder FA, et al. Helicobacter pylori eradication is superior to ulcer healing with or without maintenance therapy to prevent further ulcer haemorrhage. Aliment Pharmacol Ther 2001; 15:1939-47

[209] Liu CC, Lee CL, Chan CC, et al. Maintenance treatment is not necessary after Helicobacter pylori eradication and healing of bleeding peptic ulcer. Arch Intern Med 2003; 163:2020-4 
[210] Moayyedi P, Deeks J, Talley NJ, et al. An update of the Cochrane systematic review of Helicobacter eradication therapy in nonulcer dyspepsia: Resolving the discrepancy between systematic reviews. Am J Gastroenterol 2003; 98:2621-6.

[211] Hsu PI, Lai KH, Tseng HH, et al. Eradication of Helicobacter pylori prevents ulcer development in patients with ulcer-like functional dyspepsia. Aliment Pharmacol ther 2001; 15:195-201.

[212] Chiba N, Van Zanten SJO, Sinclair P, Ferguson RA, Escobedo S, Grace E. Treating Helicobacter pylori infection in primary care patients with uninvestigated dyspepsia: the Canadian adult dyspepsia empiric treatment-Helicobacter pylori positive (CADET-Hp) randomised controlled trial. BMJ 2002;324:1012-1016.

[213] Kuipers, EJ, Lundell, L, Klinkenberg-Knol, EC, et al. Atrophic gastritis and Helicobacter pylori infection in patients with reflux esophagitis treated with omeprazole or fundoplication. N Engl J Med 1996; 334:1018.

[214] Lundell L, Miettinen P, Myrvold HE, et al. Lack of effect of acid suppression therapy on gastric atrophy. Nordic Gerd Study Group. Gastroenterology 1999; 117:319.

[215] Schaeverbeke T, Broutet N, Zerbib F, et al. Should we eradicate Helicobacter pylori before prescribing an NSAID? Results of a placebo-controlled study. Am J Gastroenterol 2005; 100:2637-43.

[216] Annibale B, Marignani M, Monarca B, et al. Reversal of iron deficiency anaemia after Helicobacter pylori eradication in patients with asymptomatic gastritis. Ann Inten Med 1999; 131:668-72.

[217] Hacihanefioglu A, Edebali F, Celebi A, et al. Improvement of complete blood count in patients with iron deficiency anemia and Helicobacter pylori infection after the eradication of Helicobacter pylori. Hepatogastroenterology 2004; 51:313-5.

[218] Gasbarrini A, Franceschi F, Armuzzi A, Ojetti V, Candelli M, Torre ES, De Lorenzo A, Anti M, Pretolani S, Gasbarrini G. Extradigestive manifestations of Helicobacter pylori gastric infection. Gut. 1999 Jul;45 Suppl 1:I9-I12.

[219] Chan FK, Sung JY, Chan SC, et al. Randomized trial of eradication of Helicobacter pylori before non-steroidal anti-inflammatory drug therapy to prevent peptic ulcers. Lancet 1997; 350: 975-9.

[220] Gasbarrini A, Franceschi F, Taraglione R, et al. Regression of autoimmune thrombocytopenia after eradication of Helicobacter pylori. Lancet 1998; 352:878.

[221] Franchini M, Veneri D. Helicobacter pylori infection and immune thrombocytopenic purpura: an uptodate. Helicobacter 2004; 9:342-6.

[222] Fujimura K, Kuwana M, Kurata Y, et al. Is eradication therapy useful as the first line of treatment in H. pylori-positive idiopathic thrombocytopenic purpura? Analysis of 207 eradicated chronic ITP cases in Japan. Int J Hematol 2005; 81:162-8.

[223] Franchini M, Veneri D, Helicobacter pylori-associated immune thrombocytopenia. Platelets 2006; 17:712-17.

[224] Tsutsumi Y, Kanamori H, Yamato H, et al. Randomized study of H. pylori eradication therapy and proton pump inhibitor monotherapy for idiopathic thrombocytopenic purpura. Ann Hematol 2005; 84:807-11. 
[225] Leung WK, Lin SR, ching JY, et al. Factors predicting progression of gastric intestinal metaplasia: Results of a randomized trial on Helicobacter pylori eradication. Gut 2004; 53:1244-9.

[226] Mera R, Fontham ETH, Bravo LE, et al. Long term follow up of patients treated for Helicobacter pylori infection. Gut 2005; 54:1536-40.

[227] Wong BCY, Lam SK, Wong WM, et al. Helicobacter pylori eradication to prevent gastric cancer in a high risk region of China. JAMA 2004; 29:187-94.

[228] Midolo P, Marshall BJ. Accurate diagnosis of Helicobacter pylori. Urease tests. Gastroenterol Clin N Am 2000; 29:871-8.

[229] Perna F, Ricci C, Gatta L, et al. Diagnostic accuracy of a new rapid urease test (Pronto Dry), before and after treatment of Helicobacter pylori infection. Minerva Gastroenterol Dietol 2005; 51:247-54.

[230] Lee JM, Breslin NP, Fallon C, et al. Rapid urease tests lack sensitivity in Helicobacter pylori diagnosis when peptic ulcer disease presents with bleeding. Am J Gastroenterol 2000; 95:1166-70.

[231] Grino P, Pascual S, Such J, et al. Comparison of stool antigen immunoassay with standard methods for detection of Helicobacter pylori infection in patients with upper gastrointestinal bleeding of peptic origin. Eur J Gastroenterol Hepatol 2003; 15:525-9.

[232] Gisbert JP, Abraira V. Accuracy of Helicobacter pylori diagnostic tests in patients with bleeding peptic ulcer: A systematic review and meta-analysis. Am J Gastroenterol 2006; 101:848-63.

[233] Woo JS, el-Zimaity HM, Genta RM, et al. The best gastric site for obtaining a positive rapid urease test. Helicobacter 1996; 1:256-9.

[234] Chey WD, Woods M, Sheiman JM, et al. Lansoprazole and ranitidine affect the accuracy of the $14 \mathrm{C}$-urea breath test by a PH-dependent mechanism. Am J Gastroenterol 1997; 92:446-50.

[235] Laine L, Esrada R, Trujillo M, et al. Effect of proton-pump inhibitor therapy on diagnostic testing for Helicobacter pylori. Ann Intern Med 1998; 129:547-50.

[236] Dixon MF, Genta RM, Yardley JH, et al. Classification and grading of gastritis. The updated Sydney system. International workshop on the histopathology of gastritis, Houston 1994. Am J Surg Pathol 1996; 20:1161-81.

[237] El-Zimaity HM. Accurate diagnosis of Helicobacter pylori with biopsy. Gastroenterol Clin N Am 2000; 29:863-9.

[238] Huang MS, Wang WM, Wu DC, et al. Utility of brushing cytology in the diagnosis of Helicobacter pylori infection. Acta Cytol 1996; 40:714.

[239] Perez-Perez GI. Accurate diagnosis of Helicobacter pylori. Culture, including transport. Gastroenterol Clin N Am 2000; 29:879-84.

[240] Makristathis A, Hirschl AM, Lehourst P, et al. Diagnosis of Helicobacter pylori infection. Helicobacter 2004; 9:7-14.

[241] Lehours P, Ruskone-Fourmestraux A, Lavergne A, et al. Which test to use to detect Helicobacter pylori infection in patients with low grade gastric mucosa-associated lymphoid tissue lymphoma? Am J Gastroenterol 2003; 98: 291-5. 
[242] Gisbert JP, Pajares JM. Review article: 13 C-urea breath test in the diagnosis of Helicobacter pylori infection- a critical review. Aliment Pharmacol Ther 2004; 20:1001-17.

[243] Chey WD, Accurate diagnosis of Helicobacter pylori. 14-C urea breath test. Gastroenterol Clin N Am 2000; 29:895-902.

[244] Leodolter A, Domingues-Munoz JE, von Arnim U, et al. Validity of a modified 13-Curea breath test for pre- and post-treatment diagnosis of Helicobacter pylori infection in the routine clinical setting. Am J Gastroenterol 1999; 94:2100-4.

[245] Chey WD, Metz DC, Shaw S, et al. Appropriate timing of the 14 C-urea breath test to establish eradication of Helicobacter pylori infection. Am J Gastroenterol 2000; 95:1171-4.

[246] Perri F, Giampiero M, Neri M, et al. Helicobacter pylori antigen stool test and 13 Curea breath test in patients after eradication treatments. Am J Gastroenterol 2002; 97:2756-62.

[247] Gatta L, Ricci C, Tampieri A, et al. Accuracy of breath tests using low doses of 13 Curea to diagnose Helicobacter pylori infection. Gut 2006; 55:457-62.

[248] Graham DY, Opekun AR, Hammoud F, et al. Studies regarding the mechanism of false negative urea breath tests with proton pump inhibitors. Am J Gastroenterol 2003; 98:1005-9.

[249] Savarino V, Tracci D, Dulbecco P, et al. Negative effect of ranitidine on the results of urea breath test for the diagnosis of Helicobacter pylori. Am J Gastroenterol 2001; 96:348-52.

[250] Chey WD, Murthy U, Toskes P, et al. The 13 C-urea blood test accurately detects active Helicobacter pylori infection. Am J Gastroenterol 1999; 94: 1522-4.

[251] Ahmed F, Chey WD, Murthy U, et al. Evaluation of the Ez-HBT Helicobacter blood test to establish eradication. Aliment Pharmacol Ther 2005; 22:875-80.

[252] Loy CT, Irwig LM, Katelaris PH, et al. Do commercial serological kits for Helicobacter pylori infection differ in accuracy? A meta-analysis. Am J Gastroenterol 1996; 91:1138-44.

[253] Nurgalieva ZZ, Graham DY. Pearls and pitfalls of assessing Helicobacter pylori status. Dig Liver Dis 2003; 35:375-7.

[254] Ho B, Marshall BJ. Accurate diagnosis of Helicobacter pylori. Serological testing. Gastroenterol Clin N Am 2000; 29:853-62.

[255] Gisbert JP, Pajares JM, Stool antigen test for the diagnosis of Helicobacter pylori: A systematic review. Helicobacter 2004; 9:347-68.

[256] Gisbert JP, de la Morena F, Abraira V. Accuracy of monoclonal stool antigen test for the diagnosis of $\mathrm{H}$. pylori infection: A systematic review and meta-analysis. Am J Gastroenterol 2006; 101:1921-30.

[257] Odaka T, Yamaguchi T, Koyama H, et al. Evaluation of the Helicobacter pylori stool antigen test for monitoring eradication therapy. Am J Gastroenterol 2002; 97:594-9.

[258] Bravo LE, Realpe JL, Campo C, et al. Effects of acid suppression and bismuth medications on the performance of diagnostic tests for Helicobacter pylori infection. . Am J Gastroenterol 1999; 94:2380-3. 
[259] Manes G, Balzano A, Iaquinto G, et al. Accuracy of the stool antigen test in the diagnosis of Helicobacter pylori infection before treatment and in patients on omeprazole therapy. Aliment Pharmacol Ther 2001; 15:73-9.

[260] Van Leerdam ME, van Der Ende A, ten Kate FJW, et al. Lack of accuracy of the noninvasive Helicobacter pylori stool antigen test in patients with gastroduodenal ulcer bleeding. Am J Gastroenterol 2003; 98: 798-801.

[261] Pacheco N, Mago V, Gomez I, et al. Comparison of PCR and common clinical tests for the diagnosis of H. pylori in dyspeptic patients. Diagn Microbiol Infect Dis. 2001; 39:207-210.

[262] He Q, Wang JP, Osato M, et al. Real-time quantitative PCR for detection of Helicobacter pylori. J Clin Microbiol. 2002; 40:3720-3728.

[263] Meng XW, Scheer MA, Zhang HJ, Tsang TK: Detection of H. pylori from patients with PPIs treatment. ACG 2008[Poster presentation].

[264] Zsikla V, Hailemariam S, Baumann M, et al. Increased rate of Helicobacter pylori infection detected by PCR in biopsies with chronic gastritis. Am J Surg Pathol 2006; 30:242-8.

[265] Weiss J, Tsang TK, Meng X, Zhang H, Kilner E, Wang E, Watkin W. Correlation with inflammation scores and immunohistochemical and CLO test findings. Am J Clin Pathol 2008; 129:89-96.

[266] Lawson AJ, Elviss NC, Owen RJ. Real-time PCR detection and frequency of 16 S rDNA mutations associated with resistance and reduced susceptibility to tetracycline in Helicobacter pylori from England and Wales, Antimicrob Chemother 2005; 56:2826.

[267] Rimbara E, Noguchi N, Yamaguchi T, et al. Development of a highly sensitive method for detection of clarithromycin-resistant Helicobacter pylori from human feces. Current Microbiol 2005; 51:1-5.

[268] De Francesco V, Maargiotta M, Zullo M, et al. Primary clarithromycin resistance in Italy assessed on Helicobacter pylori DNA sequences by TaqMan real-time polymerase chain reaction. Aliment Pharmacol Ther 2006; 23:429-35.

[269] Kabir S. Detection of Helicobacter pylori in feces by culture, PCR and enzyme immunoassay. J Med Microbiol. 2001;50:1021-1029.

[270] Meng X, Zhang H, Law J, Tsang R, Tsang T. Detection of Helicobacter pylori from food sources by a novel multiplex PCR assay. J of food safety 2008; 28:609-619. 


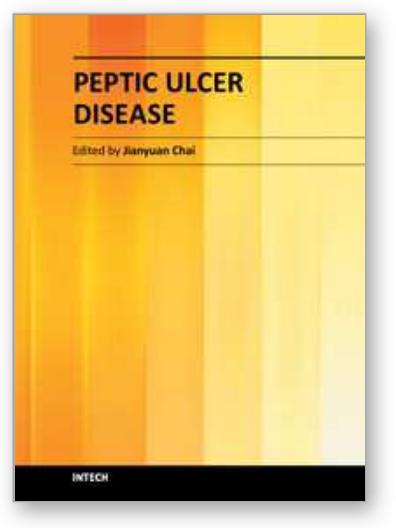

\author{
Peptic Ulcer Disease \\ Edited by Dr. Jianyuan Chai
}

ISBN 978-953-307-976-9

Hard cover, 482 pages

Publisher InTech

Published online 04, November, 2011

Published in print edition November, 2011

Peptic ulcer disease is one of the most common chronic infections in human population. Despite centuries of study, it still troubles a lot of people, especially in the third world countries, and it can lead to other more serious complications such as cancers or even to death sometimes. This book is a snapshot of the current view of peptic ulcer disease. It includes 5 sections and 25 chapters contributed by researchers from 15 countries spread out in Africa, Asia, Europe, North America and South America. It covers the causes of the disease, epidemiology, pathophysiology, molecular-cellular mechanisms, clinical care, and alternative medicine. Each chapter provides a unique view. The book is not only for professionals, but also suitable for regular readers at all levels.

\title{
How to reference
}

In order to correctly reference this scholarly work, feel free to copy and paste the following:

Tat-Kin Tsang and Manish Prasad Shrestha (2011). Helicobacter Pylori Infection in Peptic Ulcer Disease, Peptic Ulcer Disease, Dr. Jianyuan Chai (Ed.), ISBN: 978-953-307-976-9, InTech, Available from: http://www.intechopen.com/books/peptic-ulcer-disease/helicobacter-pylori-infection-in-peptic-ulcer-disease

\section{INTECH}

open science | open minds

\section{InTech Europe}

University Campus STeP Ri Slavka Krautzeka 83/A 51000 Rijeka, Croatia Phone: +385 (51) 770447 Fax: +385 (51) 686166 www.intechopen.com

\section{InTech China}

Unit 405, Office Block, Hotel Equatorial Shanghai No.65, Yan An Road (West), Shanghai, 200040, China 中国上海市延安西路65号上海国际贵都大饭店办公楼 405 单元 Phone: +86-21-62489820

Fax: +86-21-62489821 
(C) 2011 The Author(s). Licensee IntechOpen. This is an open access article distributed under the terms of the Creative Commons Attribution 3.0 License, which permits unrestricted use, distribution, and reproduction in any medium, provided the original work is properly cited. 